\title{
The Celtic Sea banks: an example of sand body analysis from very high- resolution seismic data
}

\author{
T Marsset $^{\mathrm{a},{ }^{*}}$, B Tessier ${ }^{\mathrm{b}}$, J.-Y Reynaud ${ }^{\mathrm{b}}, \mathrm{M}$ De Batist ${ }^{\mathrm{c}}, \mathrm{C} \mathrm{Plagnol}^{\mathrm{a}}$ \\ a Laboratoire `Environnements Sédimentaires', IFREMER-DRO/GM, 29280 Plouzane, France \\ b Laboratoire de Sédimentologie et Géodynamique, Université de Lille 1, 59655 Villeneuve d'Ascq, France \\ ${ }^{c}$ Renard Centre of Marine Geology, Geological Institute, University of Ghent, Krijgslaan 281-9000, Ghent, \\ Belgium \\ *: Corresponding author : T. Marsset, email address : tmarsset@ifremer.fr
}

\begin{abstract}
:
Very high-resolution seismic data from the Kaiser-I-Hind sand bank (southern Celtic Sea) recently highlighted the internal structure of the enigmatic Celtic Banks, which are among the deepest and largest shelf sand ridges. The main body of the bank is made up of 4 seismic/depositional units which reflect a transgressive evolution. New data on the detailed architecture of two of these units allow discussion of bank growth in terms of either (1) a channel-levee system preserved both by lateral migration and aggradation of the channels, or (2) a package of large offshore tidal sediment bodies (bar chains and/or giant dunes). Careful geometrical observations of seismic discontinuities make the second hypothesis more likely. The unit architecture is analysed in terms of long- to short-term processes of build-up. Long-term processes are evinced by the landward stacking of erosive sub-units in response of the last post-glacial sea-level rise, whereas short-term processes control the seaward progradation of sand bodies and fills due to the ebb predominance of the Western Channel Approaches.
\end{abstract}

Keywords: sand bank; tidal dynamics; dunes; channels; Celtic Sea; very high-resolution seismics 


\section{Introduction}

Siliciclastic shelf sand bodies result from complex interactions between relative sea-level changes and hydrodynamic processes. Sea-level controls the wide-scale, long-term evolution and preservation of these sand bodies. In turn, the building hydrodynamical processes are recorded at smaller scales in space and time. This is the case for tidal shelf sand banks (or ridges). The first depositional model for tide-dominated sand banks was outlined from seismics reflection studies in the 1960's (e.g. Houbolt, 1968). This model pointed out the overall constructional character of the banks, growing up a nd prograding in the dominant current direction (Caston, 1972). However, this model was mainly based on 2D seismic profiles of relatively poor definition. Modern numerical recording and processing of very high-resolution seismic data provide more details about the internal structure of banks. In addition, improved navigation (DGPS) provides a better correlation of distinctive reflectors between profiles at each profile-intersection point, thus permitting a detailed 3D architecture of the banks. The present paper provides a g eometrical analysis of such a detailed architecture, using as an example, the Kaiser-I-Hind bank (KIH) located in the Western Approaches of the English Channel (Celtic Sea) (Fig. 1).

The KIH bank belongs to an extensive system of elongate, linear 'en echelon' sand banks that are 70 $\mathrm{km}$ long, $7 \mathrm{~km}$ wide, up to $50 \mathrm{~m}$ high, and about $16 \mathrm{~km}$ apart. In the southern area, the banks are oriented $\mathrm{N} 10^{\circ}-20^{\circ}$ which is nearly perpendicular to the shelf edge, and their average depth is $150 \mathrm{~m}$. The KIH bank is one of those closest to the shelf break, which is about $20 \mathrm{~km}$ from the seaward end of the bank (Fig. 1). Banks are separated from their substrate by a flat surface which correlates to the sharply erosional, shelf planation surface formed during lower relative sea-level stages for PlioceneQuaternary times (Pantin and E vans, 1984). The substratum corresponds to a Lat e Miocene, progradational shelf-wedge incised by an infilled palaeovalley network that is thought to be of Late Pliocene-Early Pleistocene age (Evans and Hughes, 1984).

The first seismic profiles of the Celtic Banks were obtained by Bouysse et al. (1976). These Sparker records provided a time resolution of $20 \mathrm{~m} \mathrm{~s}$ twtt (two way travel time), so that half of the bank thickness was lost in the direct pulse. Despite the lack of data, the banks were interpreted in term of classical tidal sand banks formed during the last glacial sea-level lowstand at $-20 \mathrm{ka}$ and early stages of post-glacial sea-level rise (Stride, 1963; Bouysse et al., 1976 Bouysse et al., 1979; Pantin and Evans, 1984). This idea was supported by Belderson et al. (1986 )using a numerical model with a sealevel $100 \mathrm{~m}$ lower than present, similar to that of the last glacial period. 
In this model, tidal-current velocities are high enough to generate tidal sand banks similar to the active banks observed in the North Sea (Houbolt, 1968; Caston and Stride, 1970; Caston, 1972; Kenyon et al., 1981). The first detailed seismic image of the internal structure of the KIH bank was given by Reynaud et al. (1995). In that interpretation, the bank sensu stricto is located above the so-called « system base » which represents the link between the last stage of paleovalley infill and the first step of bank construction (Fig. 2). However, this study was based on few very high resolution seismic profiles and mainly on one longitudinal profile along the entire bank. Reynaud et al. (1995) argued for a transgressive succession and interpreted the main body of the bank as a complex of giant sand bodies (maybe dunes) migrating under the effect of the same tidal currents than those dominant at present in the area. According to transversal and longitudinal VHR seismic profiles covering the whole bank area, Reynaud (1996) hypothesised that the main seismic unit forming the bank could also correspond to channel relicts from a former lowstand deltaic system. This system would have been emplaced at the outflow of the Channel River (Gibbard, 1988) and tidally eroded during the late Quaternary sea-level change cycles (Berné et al., 1998). The very high resolution seismic data obtained during these last years have rather revealed a very complex 3D internal structure for the $\mathrm{KIH}$ bank. This is why two main hypotheses (tidal bank or eroded deltaic system) could be supported until now. The objective of this paper is to discuss further the validity of these interpretations with the help of a pseudo-3D very high resolution seismic reconstruction made for one part of the main bank body.

\section{METHODS}


The data presented herein were acquired during the Belgica 94/17 survey performed on board of the N/O Belgica in July, 1994 (Fig. 3). During this survey two parts of the KIH bank were investigated. In order to obtain detailed insight into this bank's internal structure, very-high-resolution profiles, along dense grids, were obtained using a SIG1580A sparker and a

single-channel streamer. Data were recorded using an ELICS Delph2 acquisition system and were processed at IFREMER, using SITHERE and ELICS Delph2 software. Processing steps included swell filtering, band-pass filtering and automatic gain control. Only the data obtained in the zone 2 area, located in the middle part of the southern section of the $\mathrm{KIH}$ bank are described herein. Seismic interpretation has been based on: (1) the analysis of the lateral termination of the reflectors (onlap, downlap, erosional truncation) according to the general concepts of seismic stratigraphy (Mitchum, 1977); (2) the seismic facies characteristics and (3) the correlation of distinctive reflectors between profiles. The bottom morphology of each unit has been reported from two-way travel time isochron maps. The apparent dip of reflectors within each unit were measured at every line-intersection point. True dips have been calculated using a Wulf diagram. These true dip directions have then been drawn on each isochron map. Internal structure of the Kaiser-I-Hind bank

\section{SIGNIFICANCE AND HIERARCHY OF SEISMIC SURFACES}

At the decimetric to metric scale of very high resolution seismics, seismic reflectors are interpreted as sedimentological surfaces (depositional or erosional). Three orders of seismic discontinuities have been distinguished: 
- First-order discontinuities (D) are unit boundaries. These are reflectors of largest extent and most variable amplitude, which separate seismically distinct strata. They are generally erosional surfaces, but that may be polygenic and thus possibly diachronous. They are labelled as the unit below. The bank is bounded by D40 (" system base ») at the base and D0 at the top, which is the erosive discontinuity formed by the present-day morphology of the bank.

- Second-order discontinuities are sub-unit boundaries. They separate strata with comparable seismic characteristics. They are mostly erosional surfaces that may result either from extrinsic erosion (e.g. storms) or from the migration of sharp-based prograding sedimentary bodies. When oblique regarding to the first-order discontinuity at the base, they can be used to assess the extension and long-term migration of depocentres within the unit. The basal surfaces of the sub-units, formed by migration of the sharp-based erosional sets, are therefore diachronous. their amplitude reflects lithological contrasts associated to hydrodynamical jumps and/or sedimentary lags.

- Third-order discontinuities are seismic reflectors within the sub-units and are considered to be depositional, isochronous surfaces of progradation or accretion of individual sedimentary bodies. they point out the short-term direction of sediment transport. Their spatial organisation (i.e., the seismic facies), is indicative of the lithology and/or energy of the depositional environment. 
Four main (or first-order) seismic units have been distinguished in the $\mathrm{KIH}$ bank. They are labelled from base upwards, U3, U2, U1 and U0. These units are stacked vertically. Each of them is bounded only by the units above and below, except in few cases where they scour over the unit below. They do not merge laterally anywhere. Their characteristics are illustrated on the transverse and longitudinal seismic profiles shown in Figures 4 and 5. Their bounding surfaces, including calculated true dip values, are mapped in Figures 6 to 8. Their evolution accross and along the bank is shown through examples of seismic profiles respectively in Figure 9 and Figure 10.

Unit 3 (U3)

U3 constitutes the bulk western flank of the bank. Its basal surface is erosional on the underlying paleovalley infill and/or on the system-base. U3 is composed from base to top of at least five sub units, U34, U33, U32, U31 and U30 (Fig. 4 and 5). These sub-units constitute oblique aprons 5-10 m thick. They partly overlap on each other, pointing out a long-term migration of deposits toward the NNE (fig. 6a). The second-order discontinuities are slightly erosional, with a roughly planar to slighty concave-upward geometry (Fig. 6 b, c and Fig. 9, 10). They generally dip about $2-3^{\circ}$ in a WNW direction and merge at lower angle onto the unit basal (first-order) discontinuity. The third-order discontinuities inside the sub-units are planar reflectors dipping up to $6^{\circ}$ towards the W-SW. They downlap on the sub-unit basal (second-order) surface, and are truncated at the top by the overlying sub-unit.

Unit 2 (U2) 
$\mathrm{U} 2$ is locally thicker than $30 \mathrm{~m}$ and forms the bulk central part of the bank. It is composed from base to top of three sub-units, U22, U21 and U20 (Figs. 4 and 5). They are stacked on top of each other with a lateral migration trend of deposit toward the NNE (Fig. 7a). The second-order discontinuities are overall ENE-dipping erosional surfaces. This indicates a long-term migration of depocentres toward the ENE. The second-order surfaces are undulated on the scale of hundred of meters in profiles parallel to the elongation of the bank and very irregular on transversal profiles. On isochron maps, they exhibit elongated, sinuous channel-like depressions (Fig. 7 b, c). At lowest points of these depressions, the second-order discontinuities may scour down into $\mathrm{U} 3$, or even the underlying palaeovalley infill. The sinuous depressions show a general NE-SW orientation corresponding to the present-day elongation of the bank. Their sizes tend to decrease from $\mathrm{U} 22$ to $\mathrm{U} 20$, with a decreasing width/depth ratio from about 20 to about 14 . As well, their sinuosity seems to increase significantly from U22 to U20 (Figs. 9 and 10). A detailed reconstruction of the main discontinuous depressions has been possible for U21 (Fig. 7 e). Third-order discontinuities inside the sub-units are reflectors dipping up to $10-12^{\circ}$, that may locally exhibit a cross-bed pattern. Their dip directions are variable, depending on the sinuosity of the depressions, although a dip towards the SSW seems to dominate (Fig. 7 b, c, d). This pattern suggests that the sub-units were built up by lateral accretion on the flanks of the depressions and/or by progradation to the SSW outside from the depressions. The third-order discontinuities are truncated at the top by the overlying second-order, sub-unit basal surface.

Unit 1 (U1) 
U1 constitutes a 10-20 m thick apron over the eastern and upper part of the bank. It is composed from base to top of five sub-units, U14, U13, U12, U11 and U10 (Figs. 4 and 5). These sub-units are stacked obliquely on top of each other with lateral migration, pointing out an overall long-term migration of deposits toward the NNE (fig. 8a).The oldest sub-unit U14 seems to have gradually filled and smoothed the pre-existing topographic lows. The third-order reflectors dip consistently $<6^{\circ}$ towards the S-SW (Fig. 8b). The second-order surfaces become increasingly undulated upward the unit and are also less well preserved. U1 displays a clear evolution from a lateral accretion with onlap terminations on the second-order discontinuities (U14) to a more depression-fill configuration (U10) (Figs. 9 and 10).

Unit 0 (UO)

UO corresponds to the infill of very large, elongated trenches incised parallel to each other (Figs. 4 and 5). The trench axes are oblique to the bank, with a general NNW-SSE orientation (Fig. 8c). They commonly are $500 \mathrm{~m}$ wide at the bank top, and get wider on the eastern flank of the bank (Fig. 9). The deepest incision is $30 \mathrm{~m}$ deep and reaches down to the paleovalley infill (Fig. 9 P. 79). An analysis of the scour depth range indicates that each of these incisions is dipping to the SSE (Fig . 8c). This observation excludes a connection between the different trenches into a single meandering channel form. No second-order discontinuities are pointed out in the infill. The third-order discontinuities are commonly characterised by reflectors nearly parallel to the wall of the incisions. These reflectors dip up to $10^{\circ}$ in an overall southward direction and downlap onto the incision surface. This pattern suggests an infill by lateral accretion as well as by progradation 
inside these incisions. However, some incisions with reflectors dipping eastward appear on the eastern flank of the bank, where incisions are wider ( $X, Y$ in Fig. 8c).

Figure 11 presents an overview of the seismic analysis of the $\mathrm{KIH}$ bank, showing $(\mathrm{A})$ the geometry and seismic facies of all units and sub-units, (B) the hierarchical order of the seismic discontinuities separating these units and sub-units and (C) the spatial distribution of units.

\section{INTERPRETATION}

The bank history in its regional context is beyond the scope of this paper.

Our purpose is to evidence some of the buildup mechanisms based on the detailed architectural data from the southern part of the bank. Within this framework, particular attention will be paid to $\mathrm{U} 3$ and $\mathrm{U} 2$ as major constructional phases.

Despite the various seismic configurations, it is worth noting that the third-order discontinuities in $\mathrm{U} 3$ and $\mathrm{U} 2$ display similar mean dip direction predominantly directed towards the SSW i.e. the regional oceanward dip direction of the shelf (Fig. 1). This implies thereby a predominant short-term sediment transport in this direction during the main stages of bank construction. Moreover, the sub-units have basal surfaces parallel to the elongation of the bank emphasizing that they have been deposited under the control of currents parallel to the present axis of the bank. This suggests a depositional continuity between these two sub-units. In addition, all the sub-units in U3 and U2 are stacked towards the North, i.e. in a landward direction. This landward stacking is observed throughout the all bank (Reynaud, 1996), pointing to a bank buildup under the influence of the same transgressive trend. Because they are mainly basal surfaces of downlap both in 
$\mathrm{U} 3$ and $\mathrm{U} 2$, the second-order surfaces are interpreted as diachronous surfaces of migration of sedimentary bodies. As well, the first-order unit boundary at the base of $\mathrm{U} 2$ appears as a migration surface of the same type. This suggests that the whole $\mathrm{U} 2$ is a lithosome climbing onto underlying U3. It is worth noting that within both units $\mathrm{U} 3$ and $\mathrm{U} 2$, the sedimentary bodies prograde toward the SSW but also show a depocentre migration trend toward the WNW (Fig. 11).

From these different seismic features we can deduce first that both units U3 and U2 formed under the control of comparable short-, medium- and long-term processes. In this perspective, two hypotheses should be formulated that lead in terms of depositional environments to two possible interpretations :

- U3 and U2 are genetically linked and could have been emplaced more or less synchroneously from base to top; in that condition, sub-units in $\mathrm{U} 2$ should represent migrating channels and $\mathrm{U} 3$ the levee system associated with these channels. This interpretation is consistent with that of Reynaud (1996).

- U3 and U2 are not genetically linked, U2 having climbed onto a pre-existing (older) sedimentary body represented by U3. U2 could be thus a complex of climbing tidal sand bodies prograding on a pre-existing core (U3). This second interpretation is more consistent with the previous hypothesis of Bouysse et al. (1976) and Reynaud et al. (1995).

Hypothesis of a channel-levee system 
As suspected by Reynaud et al. (1995), the bank second-order internal structure points to a long-term construction during a relative sea level rise. Regarding to the various unit internal geometries, diverse sediment bodies probably take part to the bank lithosome. Such composite structures have been already pointed out in the Flemish bank area, where cored facies successions evidence that the banks are relicts of transgressed estuarine mouth systems (Trentesaux, 1993; Berné et al., 1995). In the Celtic Bank example, the elongated sinuous depressions observed at the base of second-order surfaces within the unit U2 could correspond to preserved meandering channel floor sections. Reynaud (1996) hypothesised that the channels could be remnants of a deltaic system emplaced during lowstands of relative-sea-level at the seaward end of the Channel River (Gibbard, 1988). With respect to this interpretation, and provided that second-order surfaces are really migration surfaces of the channels, the preserved channels forms would correspond to fixed channels that would no more have been migrating laterally after incision. In a meandering channel system, this could occur only within isolated, "dead" channel limbs. The buildup of $\mathrm{U} 2$ would be the result of both lateral migration and vertical aggradation of the channels (Fig. 12a). U2 sub-units would be constituted by channel fills. This is supported by the locally cross-bedded geometry of reflectors and by chaotic aspect of related seismic facies, which suggests coarse grained sediments and/ or high energy of the depositional setting. The planar acoustic stratification in the U3 sub-units suggests lower energy and rather finer sediments. U3 could thus represent the external part of the channel system i.e. the levee deposits. This is supported by the good agreement between the depocentre migration trend (toward WNW) of both units (Fig. 11). In a context of estuarine or deltaïc mouth, one hypothesis to explain the constant westward component of channel migration is the effect of the Coriolis force, owing to the fact that the dominant flow through channels was from the North (the 
Channel River, Fig. 1). The net southward transport indicated by the third-order reflectors within the sub-units means that, if tide dominated, the estuarine system was ebbdominated.

Hypothesis of a very large 3D dunes or bar-chain system

In this interpretation, the bank is regarded as to be the result of constructional processes under tidal current action, such as for typical tidal sand banks of the North Sea (e.g. Caston, 1972). This is in accordance with previous hypotheses (Bouysse et al., 1976; Pantin and Evans, 1984; Belderson et al., 1986). The internal architecture of U2 may be interpreted as composite crossbed sets following Rubin's (1987) crossbedding model. Due to 1) the high irregularity of elongated sinuous depressions at the base of second-order, basal sub-unit surfaces, the erosional nature of these surfaces and 2) the up to $15 \mathrm{~m}$ preserved thickness of the sub-units, $\mathrm{U} 2$ could be interpreted as very large $2 \mathrm{D}$ sinuous dune package (Fig. 13a). The dune crest would be parallel to the $\mathrm{U} 2$ second-order surfaces, i.e. NW-SE. The elongated, sinuous depressions at the base of second-order surfaces would represent the migration path of scour pits at the foot of the highest parts of the dunes (Fig. 7c). The third-order surfaces dipping up to $10-12^{\circ}$ would correspond to the dune composite master bedding as in the class IV of the sand-wave model from Allen (1980). These surfaces dip toward the SW, pointing to an ebb predominance, which is still the case at present day on the bank surface (Reynaud, 1996). Alternatively, one could interpret this structure in a slight different way, as a system of bar-chain with depressions (Fig. 13b). The depressions would correspond to swatchways separating individual bars within a bar-chain. Due to the complexity of these U2 sub-units, it is difficult to choose between these alternative hypotheses for the prograding sand bodies. In the second one, 
the slope of third-order, individual bar accretion surfaces seems too high regards to $<5-10^{\circ}$ dip of active tidal bar slopes (Dalrymple and Rhodes, 1995). Whatever the case, in this interpretation U3 corresponds to the core on which the dunes/ bar-chains grew up. Thus, U3 could represent a classical linear sand bank (Houbolt, 1968). The U3 third-order surfaces, dipping to the SW, would express the migration of the bank under the action of the dominant ebb current. The U2 unit could have been deposited when the current speed increased allowing the formation of very large dunes or bar-chains which caused the erosion of a part of the initial bank core.

\section{DISCUSSION}

In absence of ground-truth, due to the lack of cores, the two interpretations remain speculative. However the details obtained thanks to the VHR seismic data on the internal structure of the bank allow us to discuss further these hypotheses.

Several problems arise from the interpration in terms of channel/levee system:

1) The base of the channel-forms in the sub-units of $\cup 2$, and mapped in Fig. $7 \mathrm{c}$ displays an irregular profile with high and low points from the North to the South (Fig. 5). This is unconsistent with that expected at the base of meandering channels, the longitudinal depositional profile of which should be plane at this scale, and nearly horizontal. Even if the depressions in the second-order surfaces are not exactly time surfaces, the diachronous effect from one point at their base to another should be very little, and would not have account for significant level changes at the base of the channels. 
2) In a meander belt depositional system, the dip directions of point bar lateral accretion surfaces are in all directions. In U2, they are mainly toward the W and/or SW (Fig. 7b,c,d). In order to explain this discrepancy, Reynaud (1996) suggested that progradation within the channel belt should have been at higher rates than lateral migration of point bars, so that only the lateral bar accretion surfaces dipping downward the channels are preserved (Fig. 12b). However, this seems relatively unlikely in the context of long-term high agradation rates responsible for $\mathrm{U} 2$ sub-unit preservation.

In addition, levee agradation surfaces are nearly horizontal in a meander belt depositional system, and everywhere parallel to the channel direction. On the contrary, in our data set, the third-order surfaces in U3 are rather perpendicular to the channel-forms (i.e. towards the South), and with slopes (up to $6^{\circ}$ ) much higher than expected inside a channel levee. Moreover, according to the relative high angle of migration of the channels within $\mathrm{U} 2$, we should expect a good preservation of interchannel facies during the buildup of such a system. This is obviously not the case in U2/U3 units in which only high dip third-order surfaces are observed.

We finally believe that the interpretation in terms of channel/levee system is difficult to maintain. This leads us to privilege the hypothesis that the main corpus (U2) of the $\mathrm{KIH}$ bank represents a complex of giant tidal dunes or bar-chains that would have migrated and climbed on the gentle dipping flank (stoss-side) of a pre-existing linear tidal sand bank (U3). With respect to larger scale data on the $\mathrm{KIH}$ bank in the framework of the PlioQuaternary of the Celtic Sea (Pantin and Evans, 1984; Reynaud, 1996), the buildup would have occured during the first stages of the last post-glacial sea-level rise (18-15 KY). At this time, according to these authors, the study area was a wide-open gulf of about $60 \mathrm{~m}$ 
maximum depth, subject to the action of powerfull tidal streams (Belderson et al., 1986), and episodically, of oceanic storm swells. In this bank history, we believe that the unit U1 which displays somewhat similar seismic characters than $\mathrm{U} 2$, but points for a lower aggradation rate, built up during a stage of the bank construction when tidal transports were largely constrained by swell action. The deep incisions on top of the bank (U0) are thought to represent troughs scoured between the dunes (bars ?) of U1. In that way, the unit $\cup 0$ could correspond to the remnant of a last tidal dune (bar ?) complex construction controlled by very high energy tidal currents and that occurs before the final erosional morphogenesis and abandonment of the bank, correlatively to its sea-level rise induced deepening.

\section{CONCLUSION}

The $\mathrm{KIH}$ bank is regarded as a transgressive succession of 4 transgressive depositional units emplaced and preserved in favor of the last post-glacial sea level rise. The detailed pseudo-3D architecture of two of these units highlight this idea. Both units forming the bulk of the bank are of very different structure but they are reflecting the same buildup patterns. These patterns are : (1) the long-term landward stacking of deposits during the bank construction, and (2) the simultaneous short-term overall progradation of sediments through the Western Channel Approaches toward the ocean. At the outcrop scale which is the scale of very high resolution seismics, the complexity of the bank internal architecture is to be discussed in terms of relationships between composite, active individual sediment bodies (for which 3D models are known), and how these sediment bodies are preserved in the fossil record. The example of the KIH bank highlights the role of autocyclic surfaces as sub-unit boundaries, which are the surfaces of migration of various prograding sediment 
bodies. It seems possible to assess the depositional setting and dynamics from the unit architecture.Two hypotheses are proposed. In the first one, the bulk of the bank is made up of a subarerial meandering channel-levee system which developped in a deltaïc/estuarine setting. In the second one, it corresponds to the stack of giant 2D sinuous tidal dunes or bar-chains climbing onto an old tidal linear bank core. Geometrical constraints on the slope of erosional migration surfaces at the base of the sub-units and of depositional progradation/accretion surfaces inside suggest that only the second hypothesis is likely. HPC cores are still needed to precise the age and environmental setting during the bank growth (lithology, bathymetry ... ).

\section{ACKNOWLEDGEMENTS}

This work was conducted during the project MAST2 STARFISH, funded by the EEC. We thank Profs. G. De Moor (University of Gent) and H. Chamley (University of Lille) for permitting the organization of research within this European framework. We thank Prof. R.W. Dalrymple (Queen's University Canada) for its detailed and very usefull comments which greatly improved our understanding of this sand body. The final version largely benefited from comments of the journal reviewers, Profs. D.J. Beets and L. Carter. J.-F. Bourillet and G. Lericolais (IFREMER) are thanked for their help during the first bathymetric and seismic acquisitions on the Kaiser-I-Hind bank during the previous SEDIMANCHE surveys performed in the framework of the SEDIMANCHE Project initiated by S. Berné (IFREMER). We thank GENAVIR and the crew of the R/V Belgica for their technical assistance during the survey Belgica94/17.

\section{REFERENCES}


Allen, J.R.L., 1980. Sand waves: a model of origin and internal structure. Sediment. Geol., $26,281-328$.

Belderson, R.H., Pingree, R.D., Griffiths, D.K., 1986. Low sea-level tidalorigin of Celtic sea sand banks - Evidence from numerical modelling of M2tidal streams. Mar. Geol., 73, 99108.

Berné, S., Trentesaux, A., Stolk, A., Missiaen, T., De Batist, M., 1995. Architecture and long term evolution of a tidal sandbank: the Middelkerke Bank (southern North Sea). Mar. Geol., 121, 57-72.

Berné, S., Marsset, T., Lericolais, G., Bourillet, J.-F., De Batist, M.,1998. Erosional offshore sand ridges and lowstand shorefaces: examples from tide and wave dominated environments around France. J. Sed. Res., 68 (4), 540-555.

Bouysse, P., Horn, R. Lapierre, F., Le Lann, F., 1976. Etude des grands bancs de sable du Sud-Est de la Mer Celtique. Mar. Geol., 20, 251-275.

Bouysse, P., Le Lann, F., Scolari, G., 1979. Les sédiments superficiels des approches occidentales de la Manche. Mar. Geol., 29, 107-135.

Caston, V.N.D., Stride, A.H., 1970. Tidal sand movement between some linear sand banks in the North Sea off northeast Norfolk. Mar. Geol., 9, M38-M42. 
Caston, V.N.D., 1972. Linear sand banks in the Southern North Sea. Sedimentology, 18, 63-78.

Dalrymple, R.W., Rhodes, R.N., 1995. Estuarine dunes and bars. In: G.M.E. Perillo (Ed.), Geomorphology and Sedimentology of Estuaries, Developments in Sedimentology, Elsevier Science, pp. 359-422.

Evans, C.D.R., Hughes, M.J., 1984. The Neogene succession of the South Western Approaches, Great Britain. J. Geol. Soc. London, 141, 315-326.

Gibbard, P.L., (1968). The history of the great northwest European rivers during the past three million years, Phil. Trans. R. Soc. London B, 318, 559-602.

Houbolt, J.J.H.C., 1968. Recent sediments in the Southern Bight of the North Sea. Geol. Mijnb., 47, 245-273.

Kenyon, N.H., Belderson, R.H., Stride, A.H., Johnson, M.A., 1981. Offshore tidal sandbanks as indicators of net sand transport and as potential deposits. In: Nio, S.D., Schättenhelm, R.T.E., van Weering, T.C.E. (eds.) Holocene marine sedimentation in the North Sea Basin. Spec. Publ. Int. Ass. Sedimentol., 5, 257-268.

Mitchum, R.M., Vail, P.R., Sangree, J.B., 1977. Stratigraphic interpretation of seismic reflection patterns in depositional sequences. In: Payton, C.E. (ed.) Seismic stratigraphy Application to hydrocarbon exploration. Am. Ass. Petr. Geol. Spec. Publ., 26, 117-133. 
Pantin, H.M., Evans, C.D.R., 1984. The Quaternary history of the central and southwestern Celtic Sea. Mar. Geol., 57, 259-293.

Reynaud, J.Y., Tessier, B., Proust, J.N., Lericolais, G., Marsset, T., Berne, S., Chamley, H., 1995. Apports de la sismique très haute resolution à l' interprétation génétique d'un banc sableux de la Mer Celtique. C. R. Acad. Sci. Paris, 320 (II), 125-132.

Reynaud, J.Y., 1996. Architecture et evolution d'un banc sableux de Mer Celtique meridionale. Unpublished thesis, University of Lille, $185 \mathrm{p}$.

Reynaud, J.Y., Tessier, B., Proust, J.N., Dalrymple, R.W., Marsset,T., De Batist, M., Bouriller, J.F., Lericolais, G., 1998. Eustatic and hydrodynamic controls on the architecture of a deep shelf sand bank (Celtic Sea). Sedimentology (accepted).

Rubin, D.M. , 1987. Cross-bedding, bedforms, and paleocurrents. SEPM Concepts in Sedimentology and Paleontology series $n^{\circ}$ 3. Tulsa, Oklahoma.

Stride, A.H., 1963. Current-swept sea-floors near the the southern half of Great Britain. Quaterly J. Geol. Soc. Lond., 119, 175-199.

Tessier, B., 1997. Expressions sédimentaires de la dynamique tidale. Mémoire d'habilitation à diriger des recherches en Sciences Naturelles, University of Lille.

Trentesaux, A., 1993. Structure interne et dynamique sédimentaire du Middelkerke Bank, Mer du Nord Méridionale. Unpublished thesis, University of Lille, 229 p. 


\section{LIST OF CAPTIONS}

Fig. 1 : localisation of the study area on the Armorican margin

Fig. 2 : stratigraphic units of the Kaiser-I-Hind bank

Fig. 3 : track lines of the investigated area (Belgica 94/17 survey)

Fig. 4 : transversal seismic profile from the Kaiser-I-Hind bank

Fig. 5 : longitudinal seismic profile from the Kaiser-I-Hind bank

Fig. 6 : seismic unit U3 :

a. spatial distribution of the sub-units

b.U32 : isochron map of the bottom and true dip values

c.U31 : isochron map of the bottom and true dip values

Fig. 7 : seismic unit U2 :

a. spatial distribution of the sub-units

b.U22 : isochron map of the bottom and true dip values

c.U21 : isochron map of the bottom and true dip values

d.U20 : isochron map of the bottom and true dip values

Fig. 8 : seismic units $\mathrm{U} 1$ and $\mathrm{U} 0$ :

a. spatial distribution of the sub-units of $\mathrm{U} 1$

b.U14 : isochron map of the bottom and true dip values

c.U0 : isochron map of the bottom and true dip values

Fig. 9 : evolution of the internal structure across the KIH bank from the North to the South

Fig. 10 : evolution of the internal structure of the $\mathrm{KIH}$ bank along the longitudinal profile P.59

Fig. 11 : synthetical results of the seismic analysis

Fig. 12: 

a. hypothesis of a channel/ levee system
b. migration of lateral bars with high progradation velocity

Fig. 13 :
a. hypothesis of a dunes system
b. hypothesis of a bar - chain system 

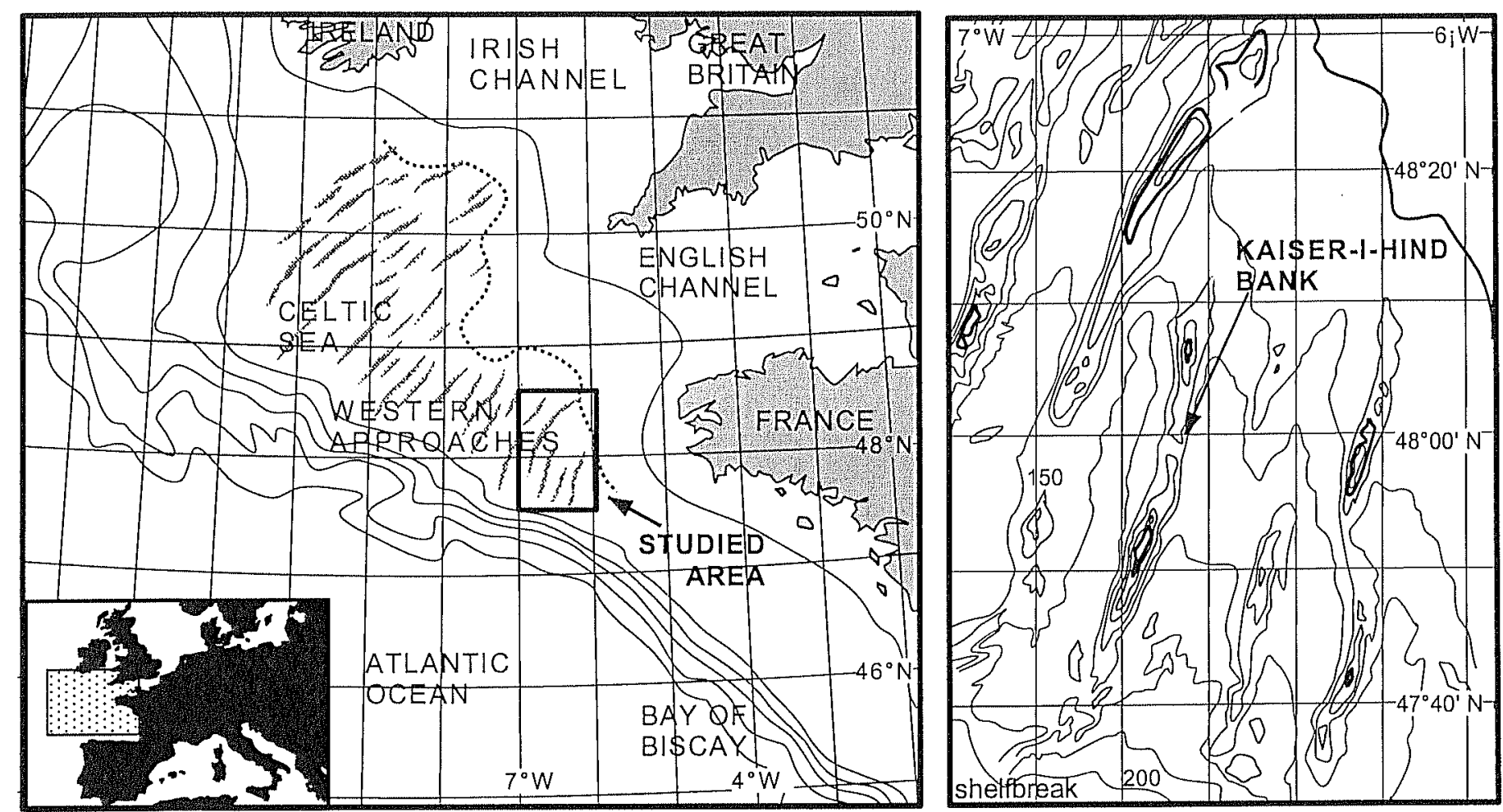

Fig.1 : Location map showing the position of the Kaiser-1-Hind sand bank. Bathymetry in meters. 


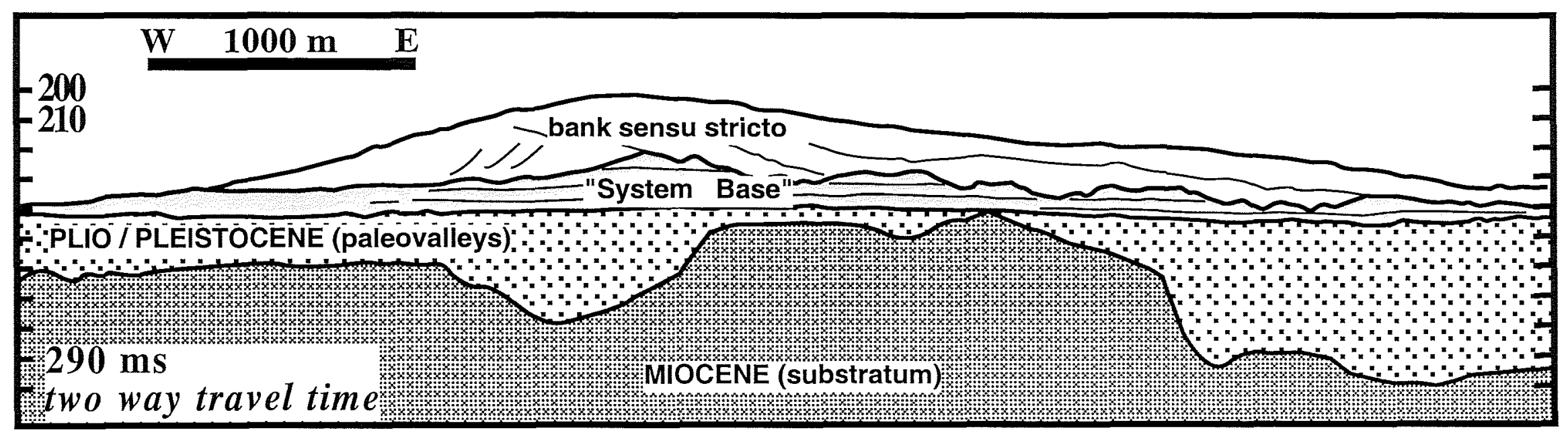

Fig.2. Major stratigraphic units with and beneath the Kaiser-I-Hind sand bank (from Reynaud, 1996). 


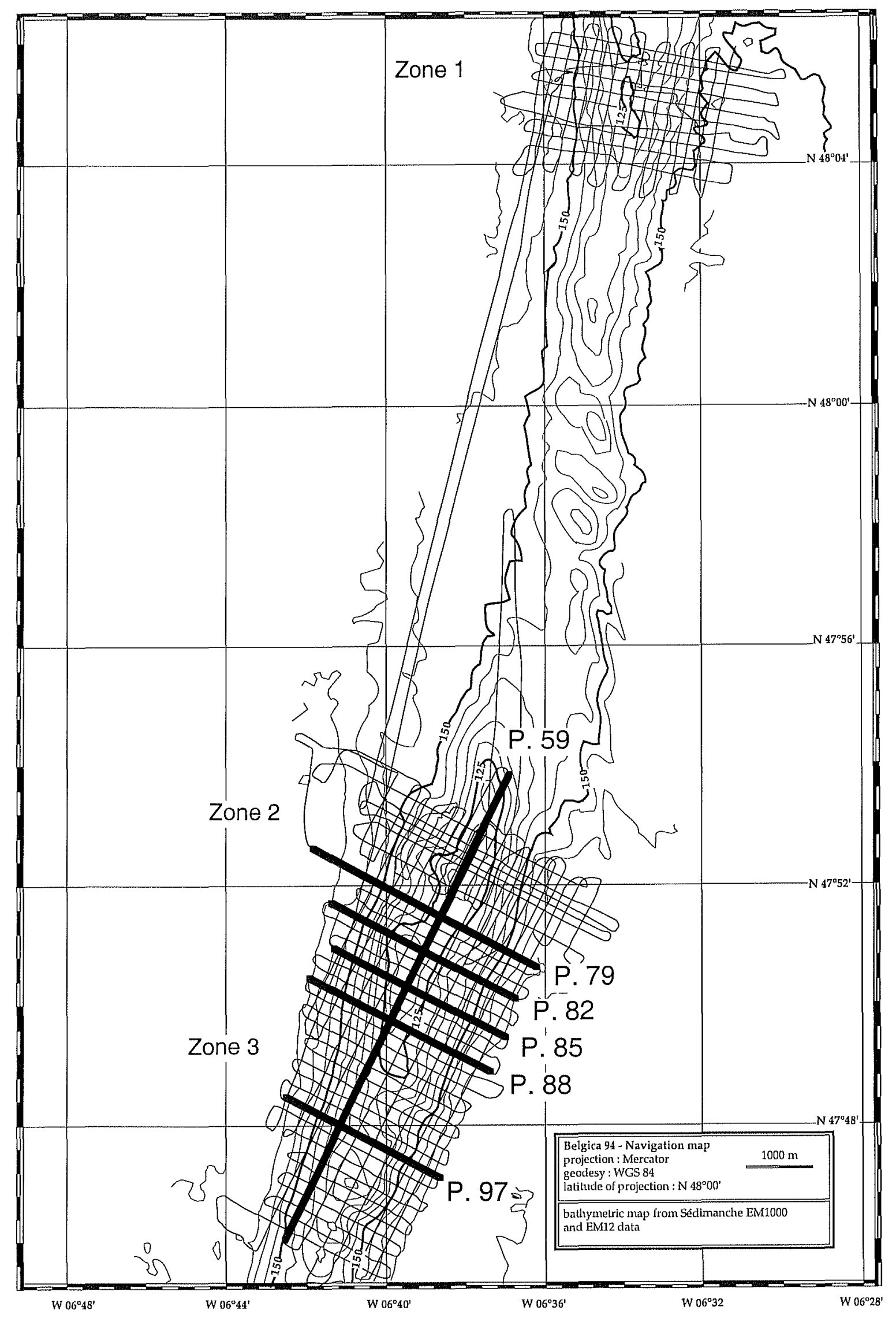

Fig. 3. Location of the profiles recorded during the Belgica 94/17 survey over the Kaiser-I-Hind bank. 


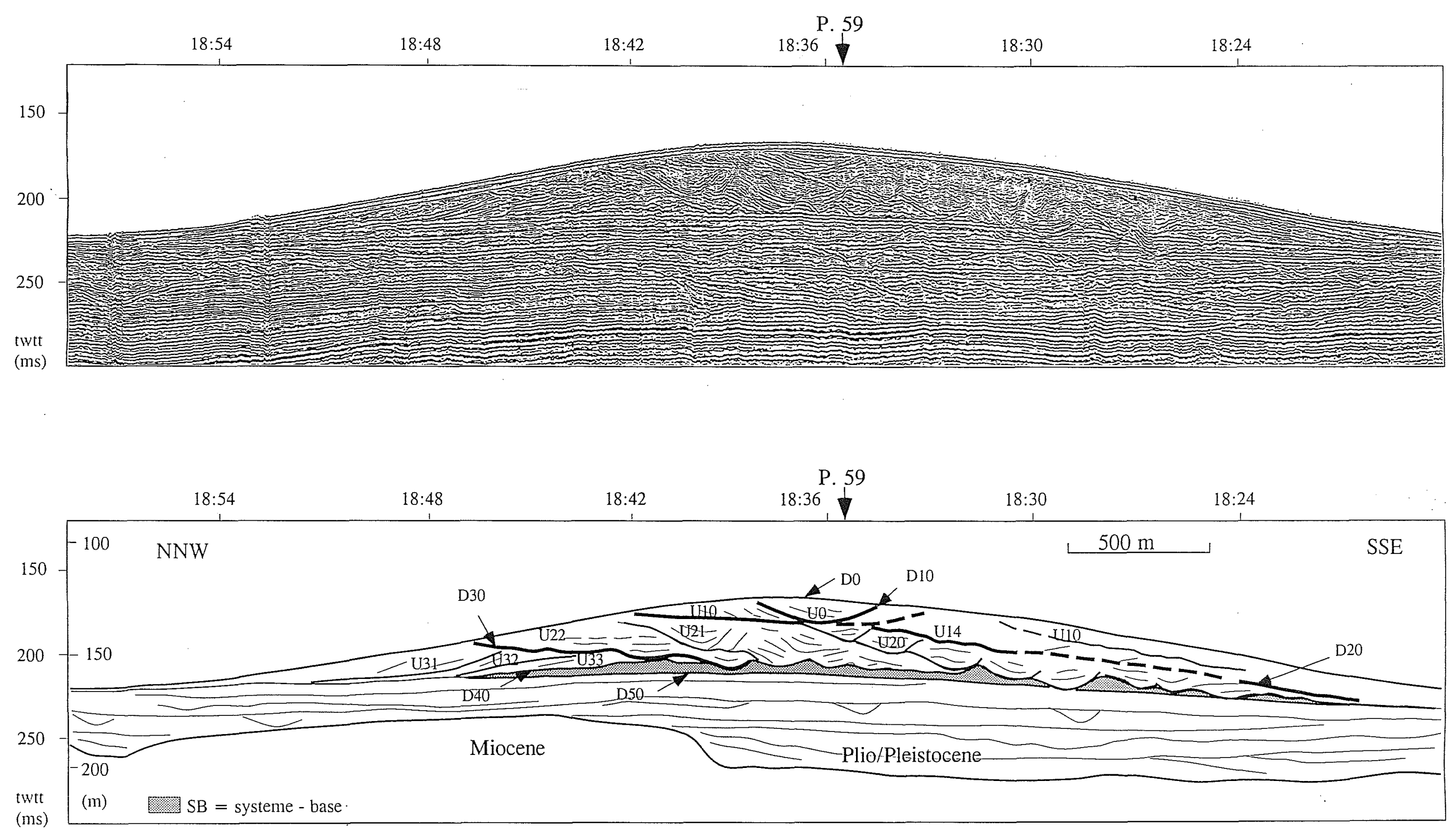

Fig. 4. Transversal seismic profile (P. 88) from the Kaiser-I-Hind bank showing seismic sub-units (U0 to U33) and major discontinuities (D0 to D50). For location, see Fig. 3. 

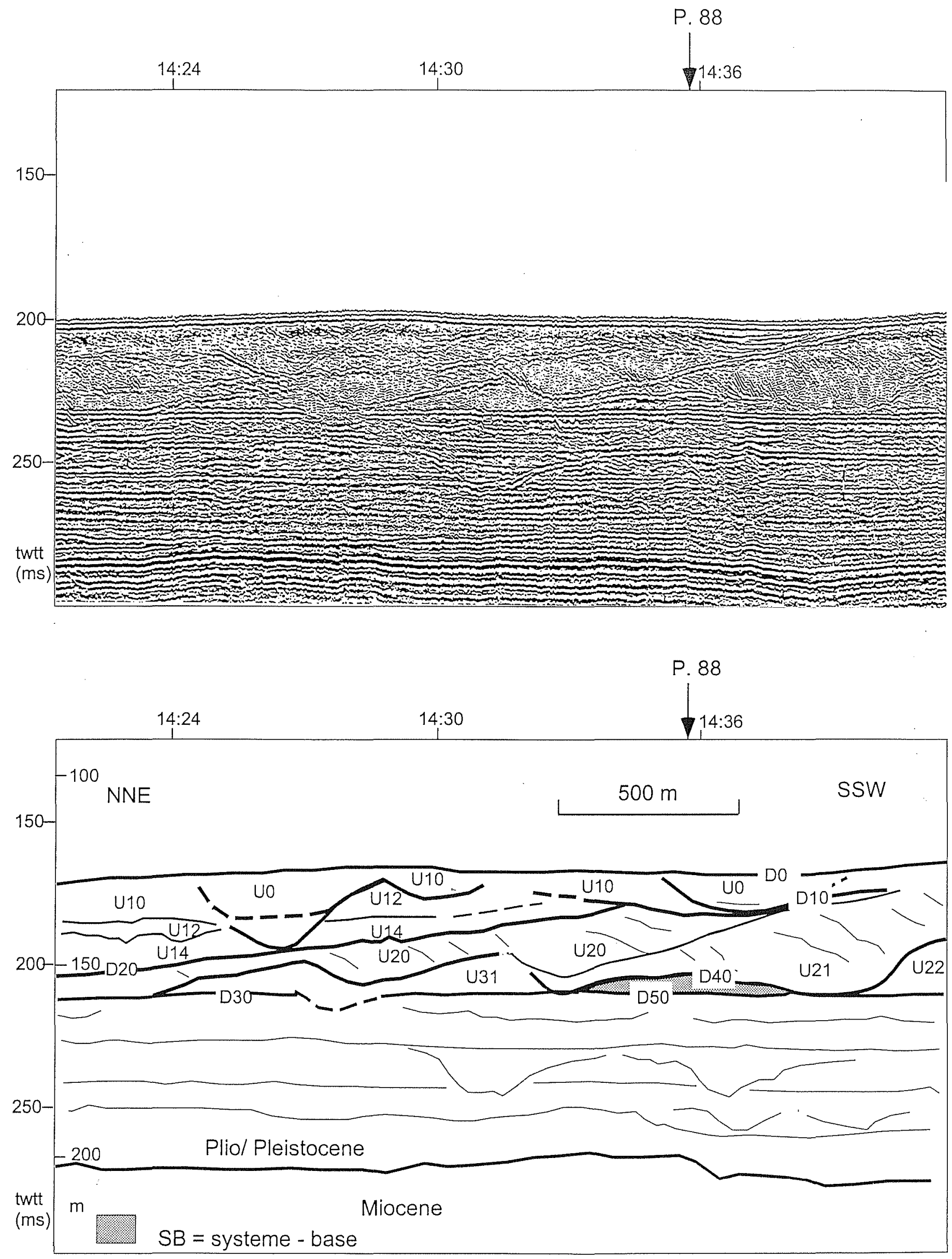

Fig. 5. Longitudinal seismic profile (P. 59) from the Kaiser-I-Hind bank showing seismic sub-units ( $\cup 0$ to U33) and major discontinuities (D0 to D50). For location, see Fig. 3. 


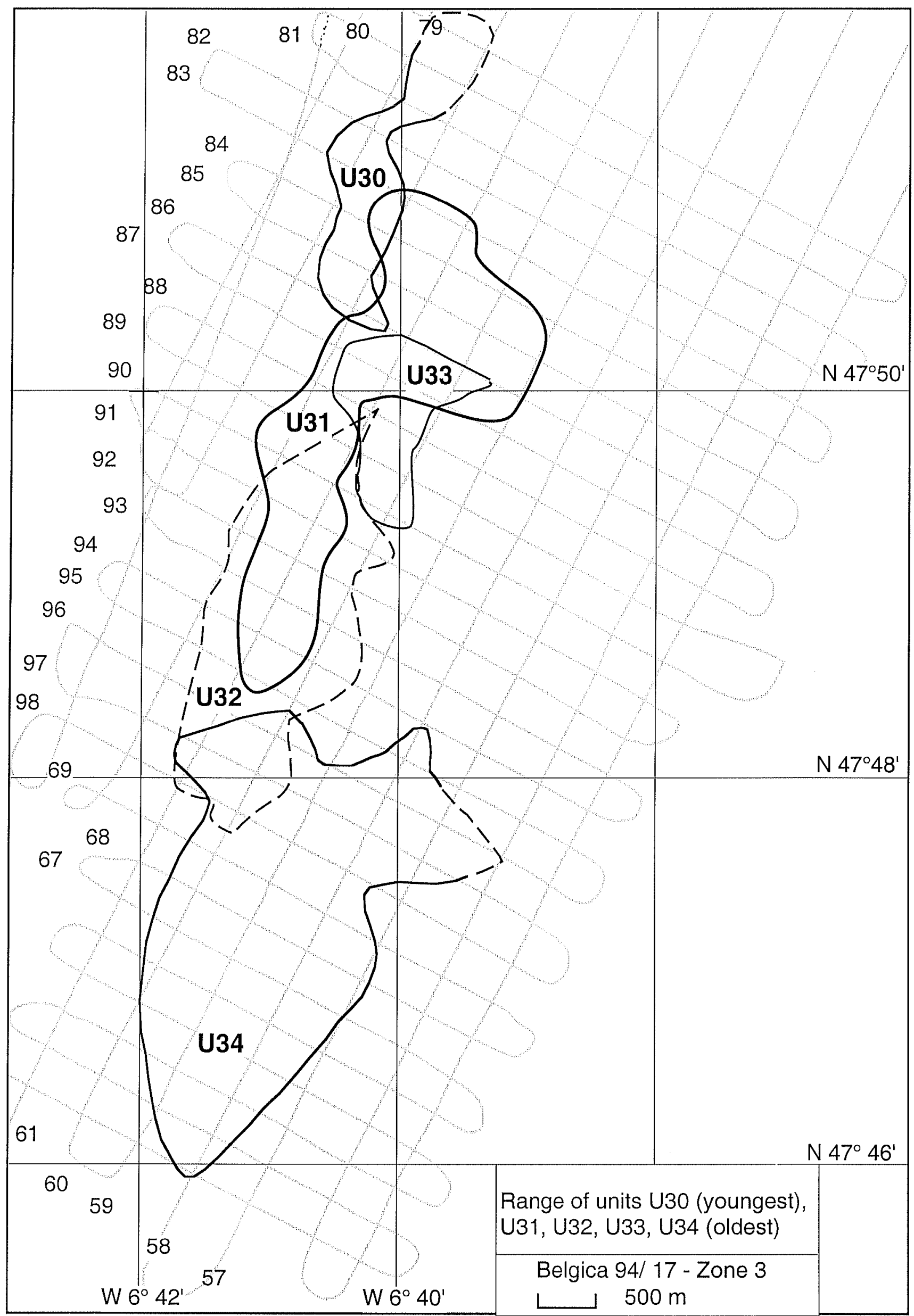

Fig. 6a. Spatial distribution of the U30s sub-units 


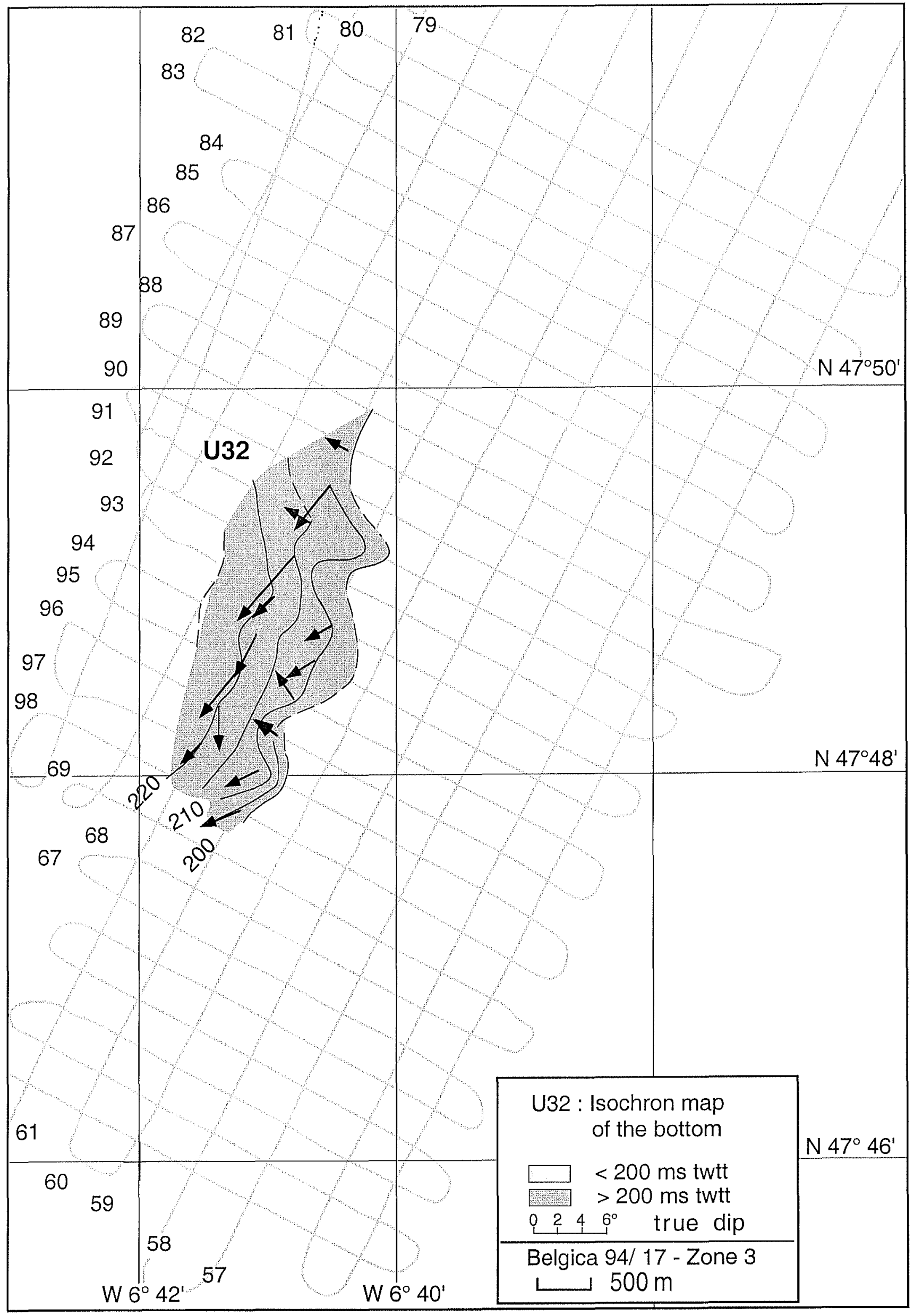

Fig. 6b. Seismic sub-unit U32 : Isochron map of the bottom and true dip values of the internal reflectors within U32. Arrow lenght indicates dip value. 


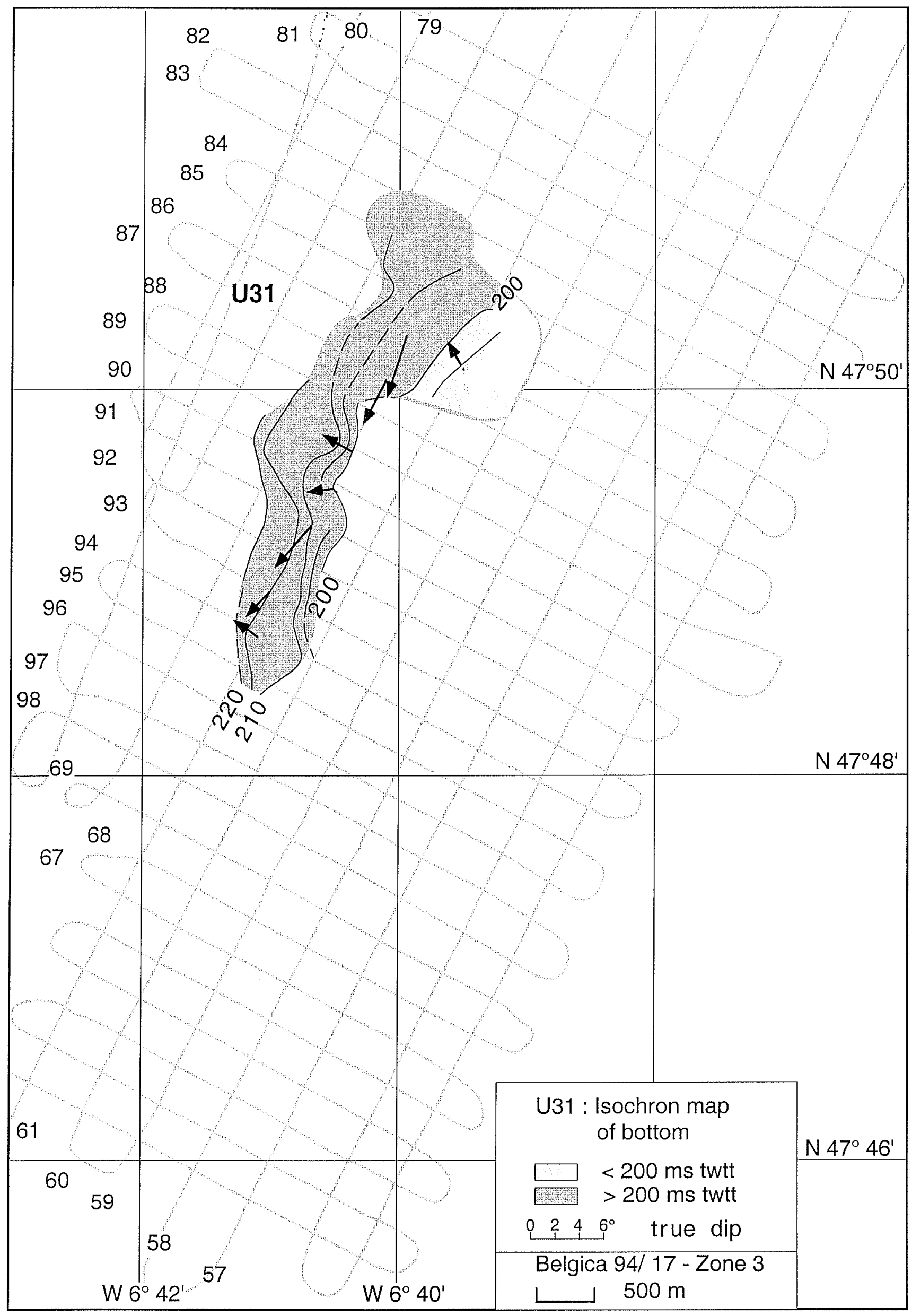

Fig. 6c. Seismic sub-unit U31 : isochron map of the bottom and true dip values of the internal reflectors within U31. Arrow lenght indicates dip value. 


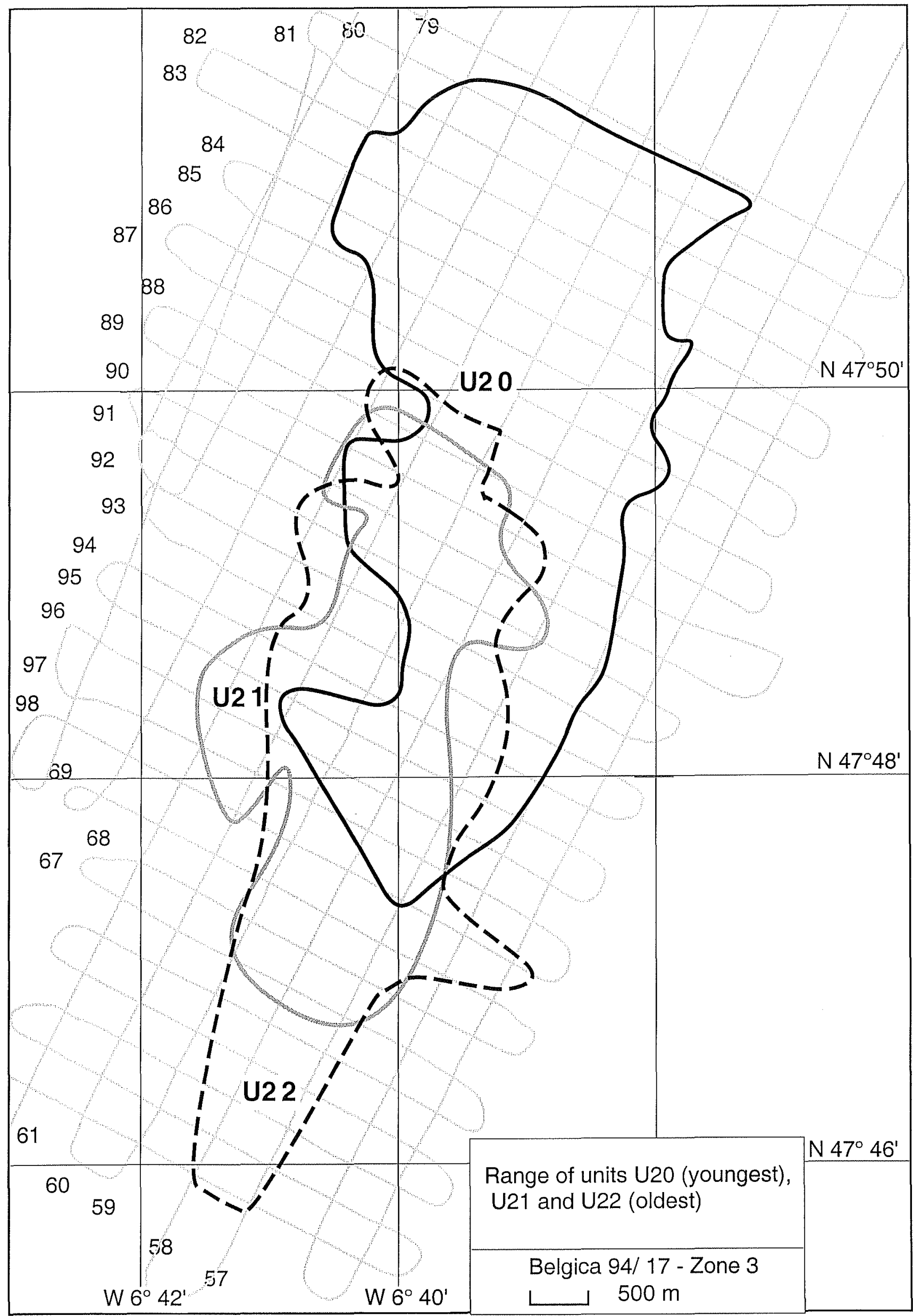

Fig. 7a. Spatial distribution of the U20s sub-units 


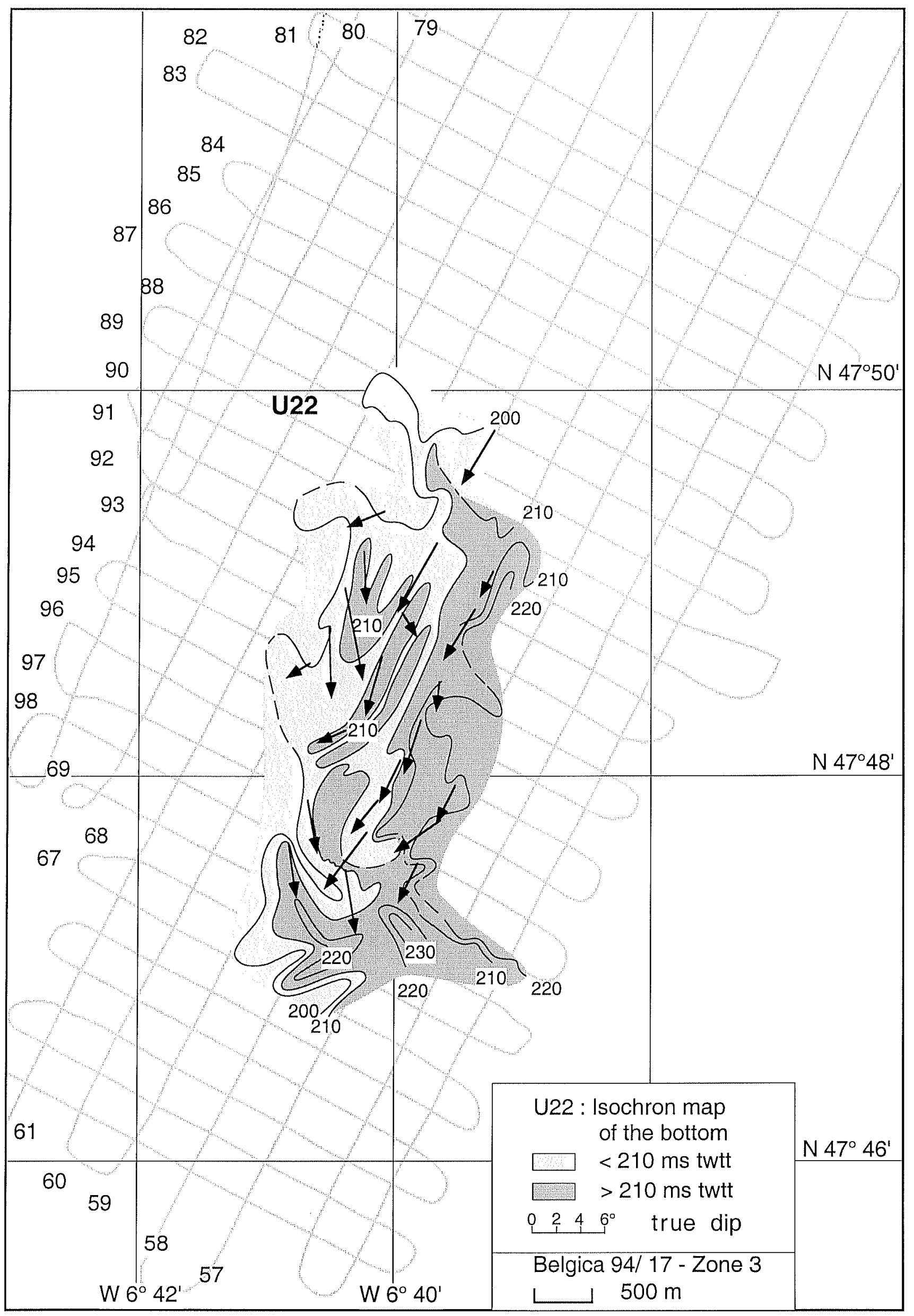

Fig. 7b. Seismic sub-unit U22 : Isochron map of the bottom and true dip values of the internal reflectors within U22. Arrow lenght indicates dip value. 


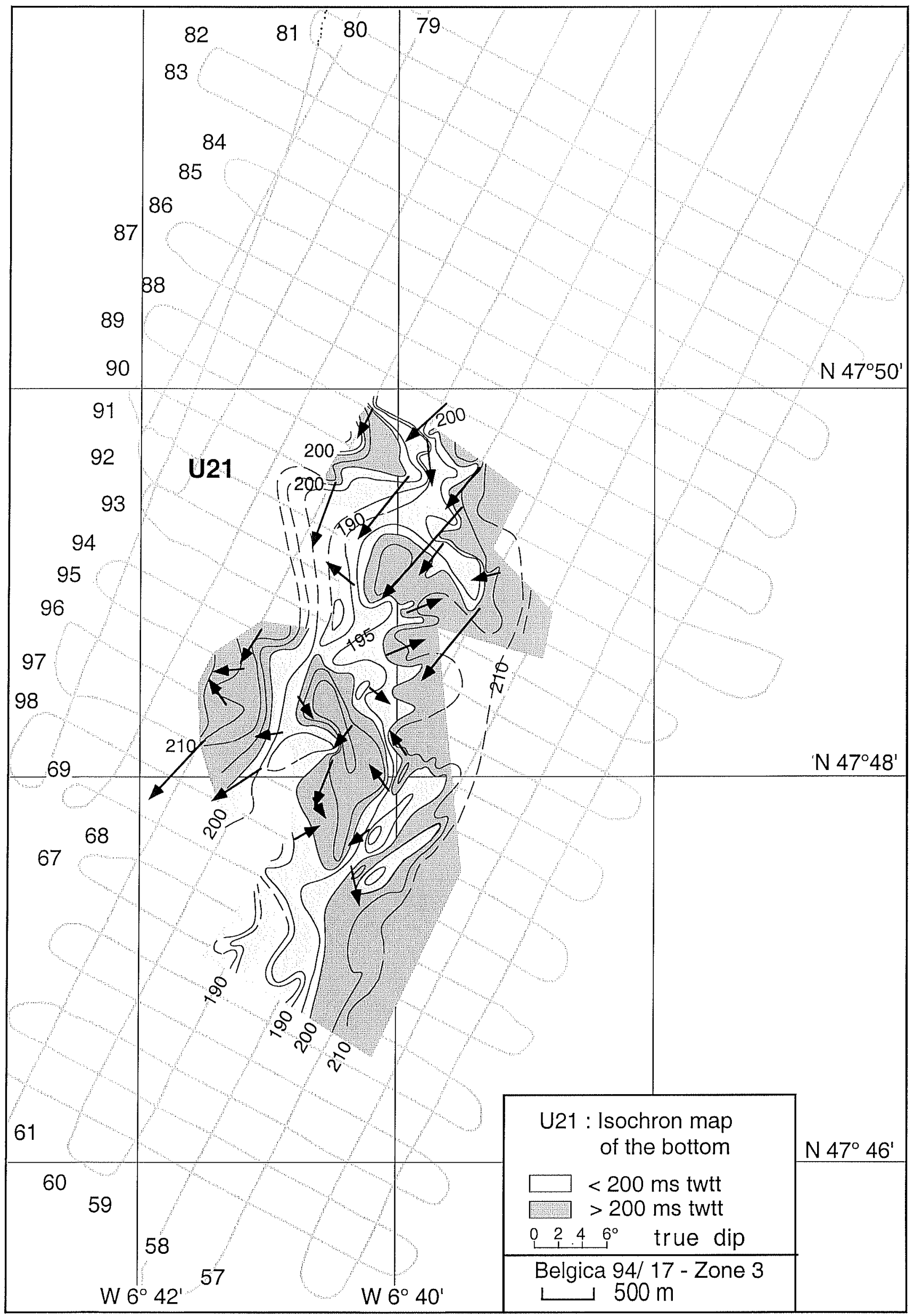

Fig. 7c. Seismic sub-unit U21 : isochron map of the bottom and true dip values of the internal reflectors within U21. Arrow lenght indicates dip value. 


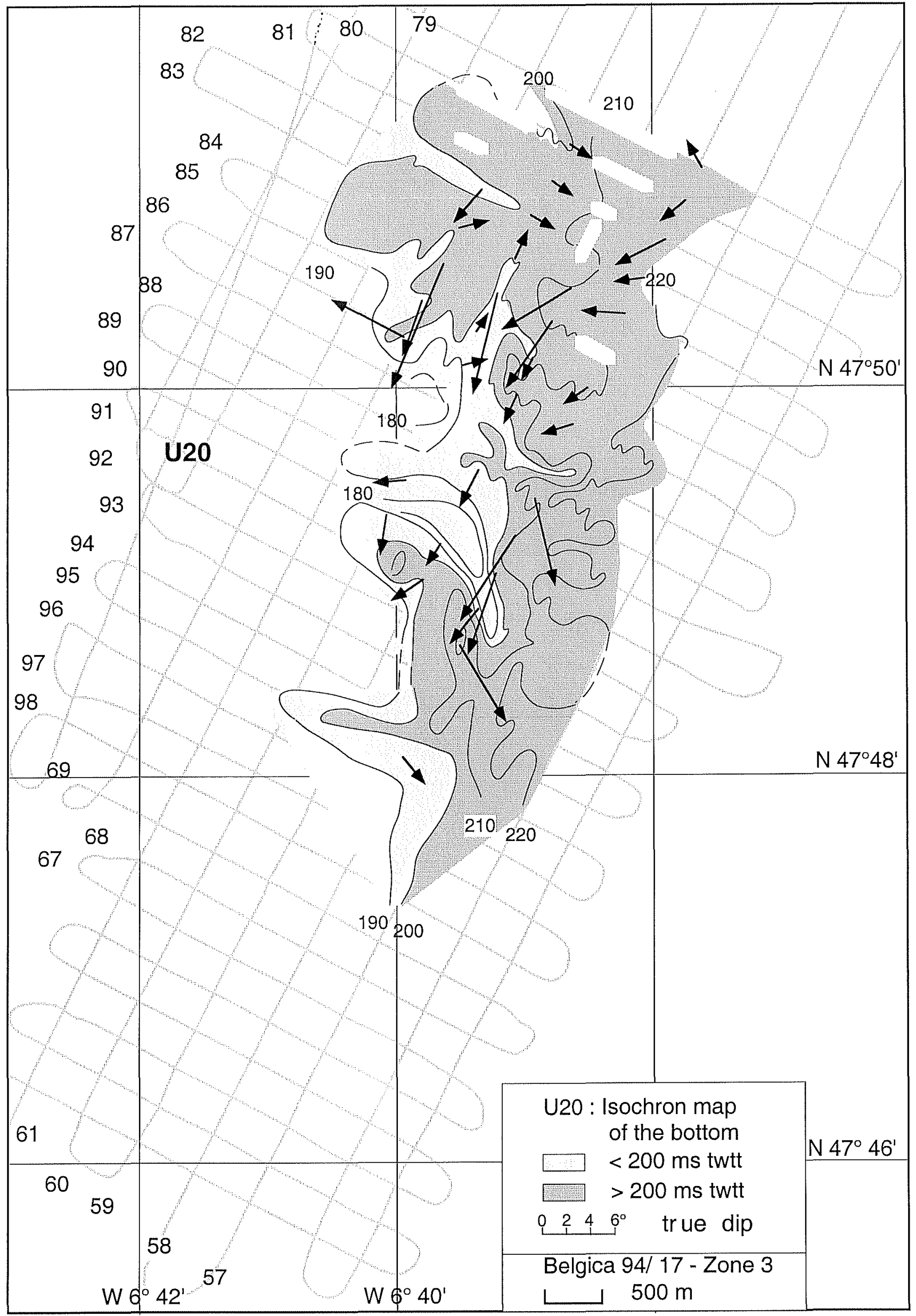

Fig. 7 d. Seismic sub-unit U20 : Isochron map of the bottom and true dip values of the internal reflectors within U20. Arrow lenght indicates dip value. 


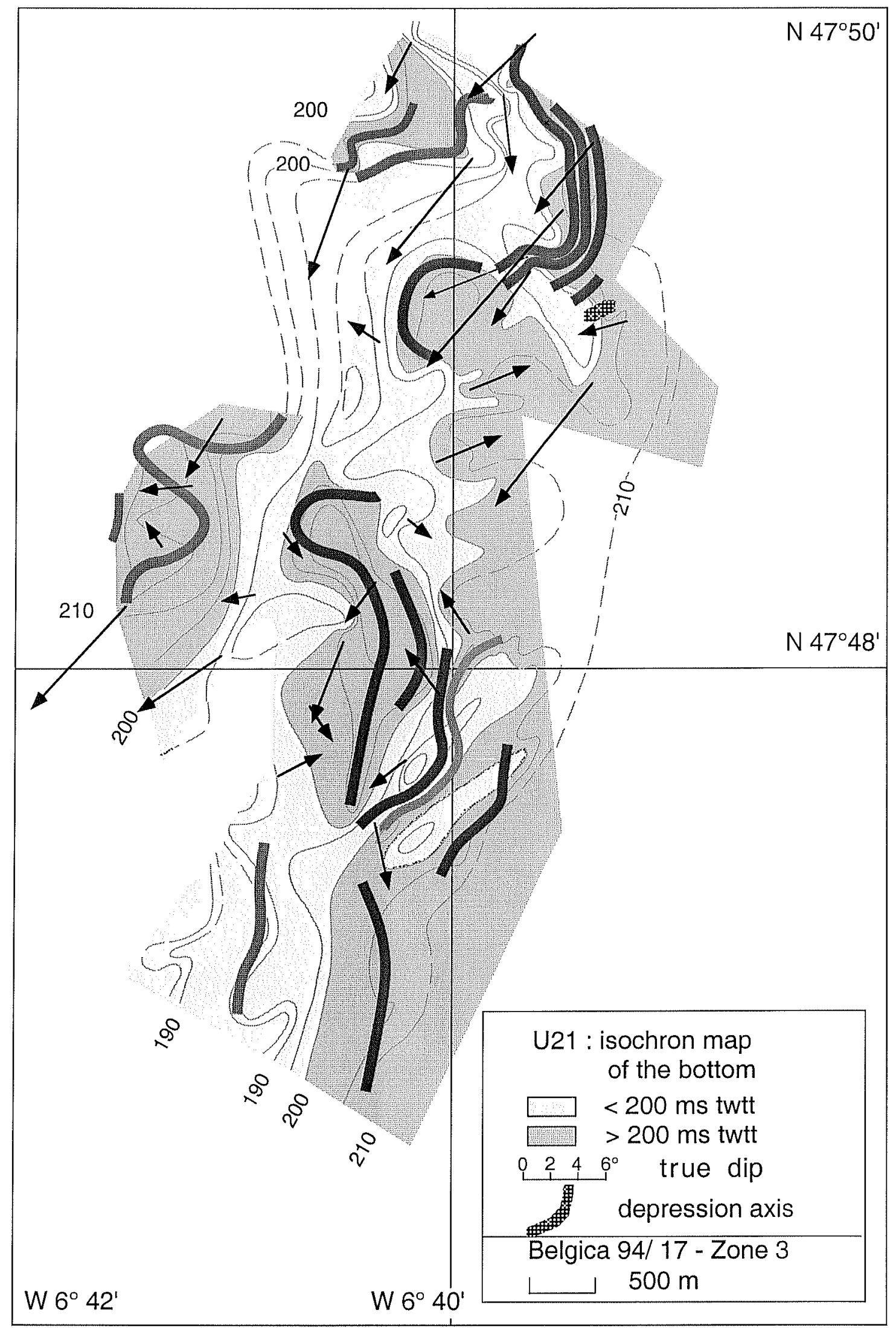

Fig. 7e. Seismic sub-unit U21 showing the depression axes 


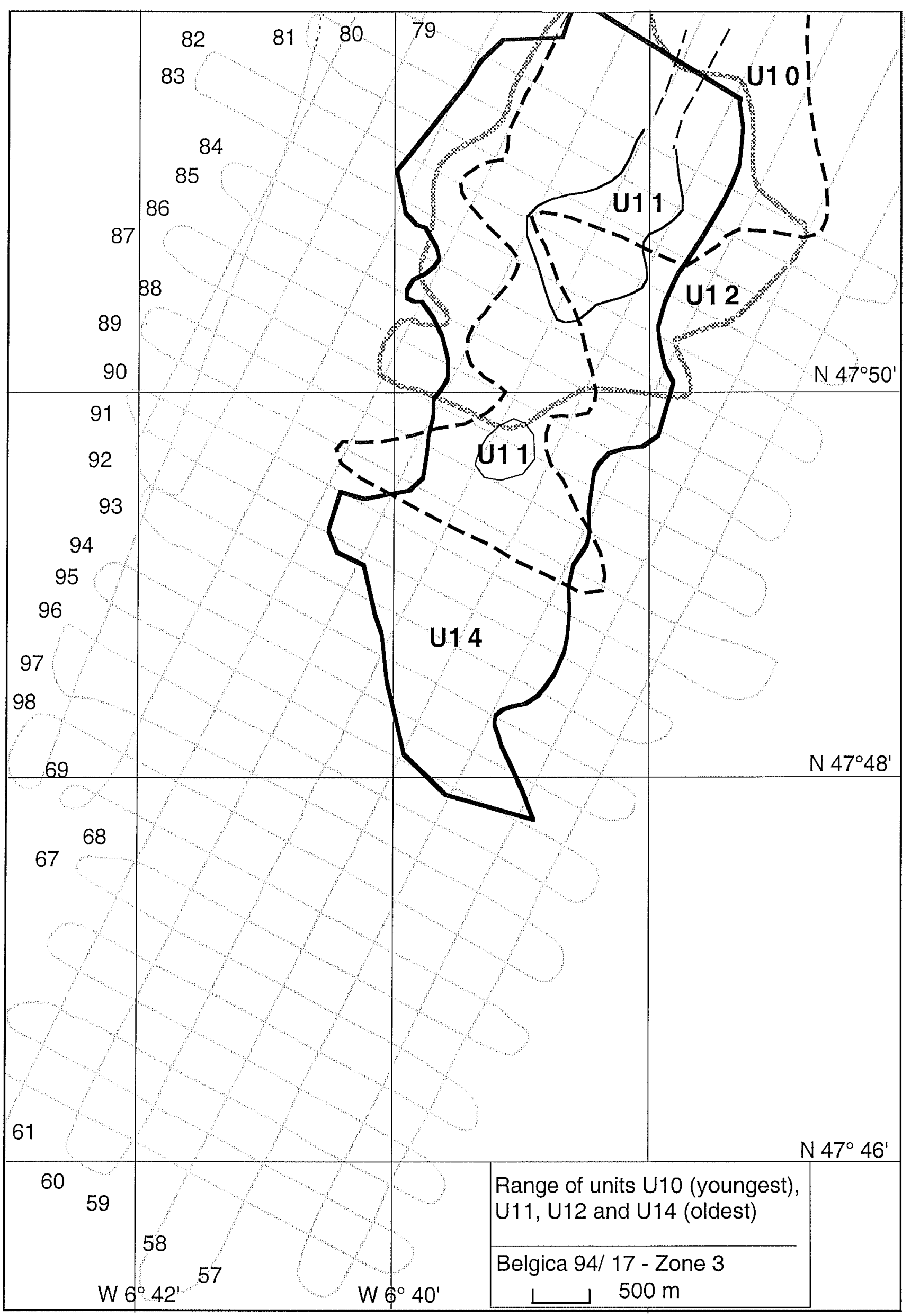

Fig. 8a. Spatial distribution of the U10s sub-units 


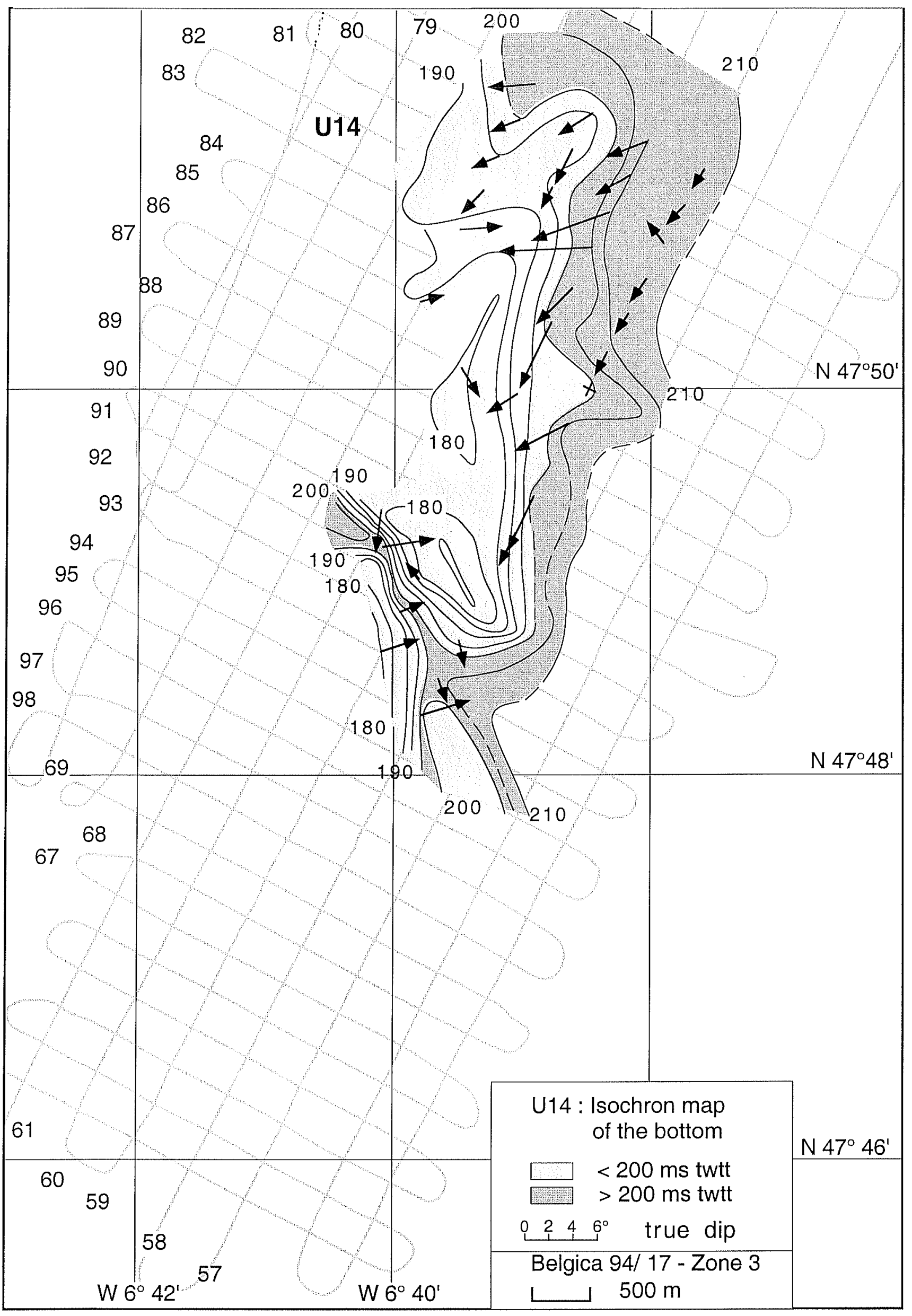

Fig. 8b. Seismic sub-unit U14 : isochron map of the bottom and true dip values of the internal reflectors. Arrow lenght indicates the dip value. 


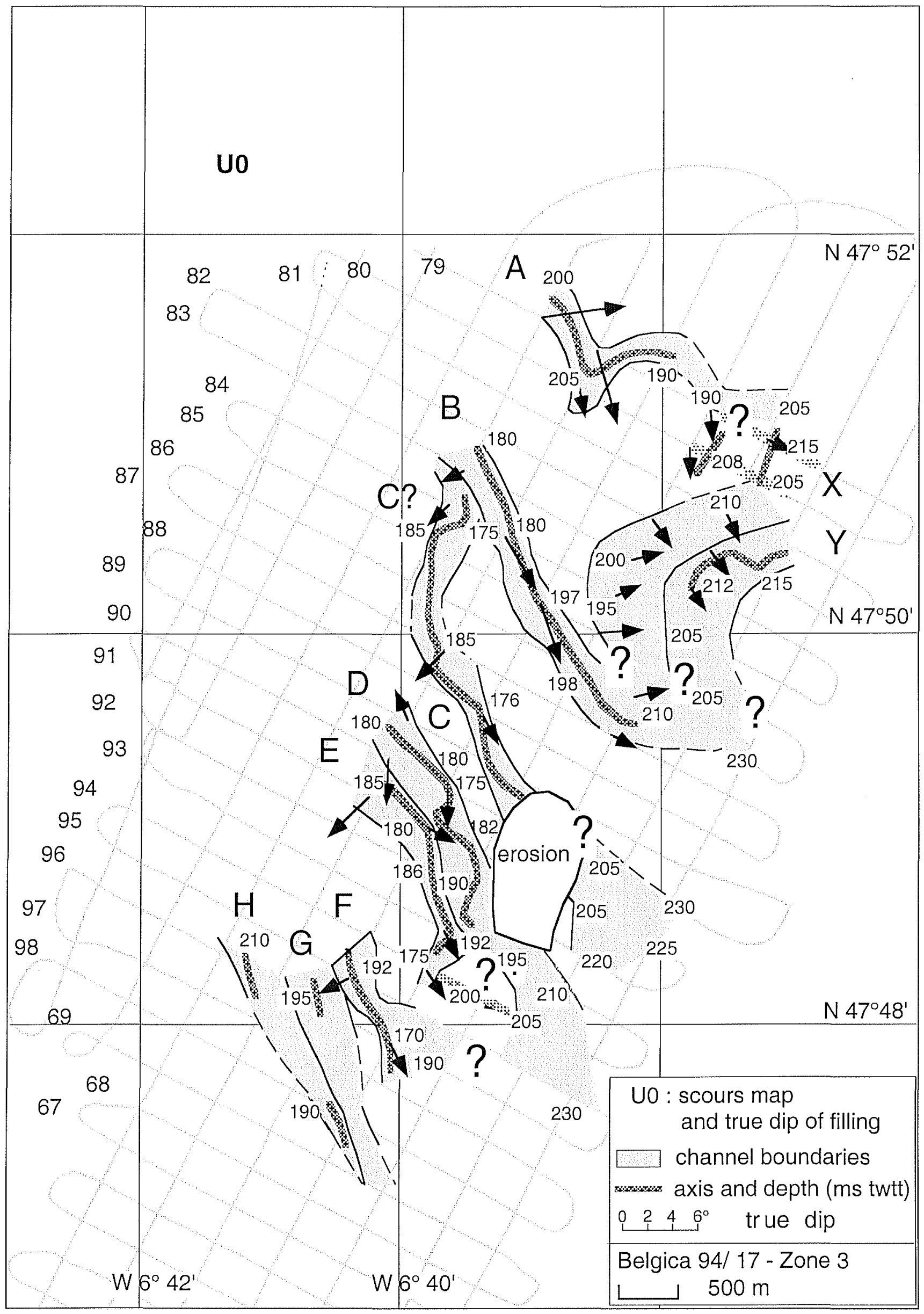

Fig. 8c. Seismic unit U0 showing oblique scours across the Kaiser-I-Hind bank. Arrow length indicates dip value. 
NNW

profile 59

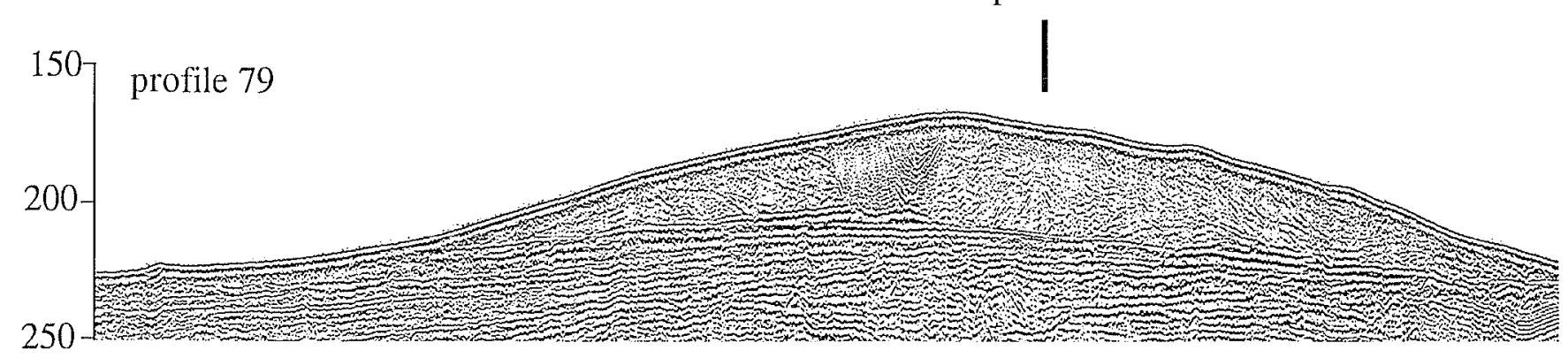

ms twtt

profile 59

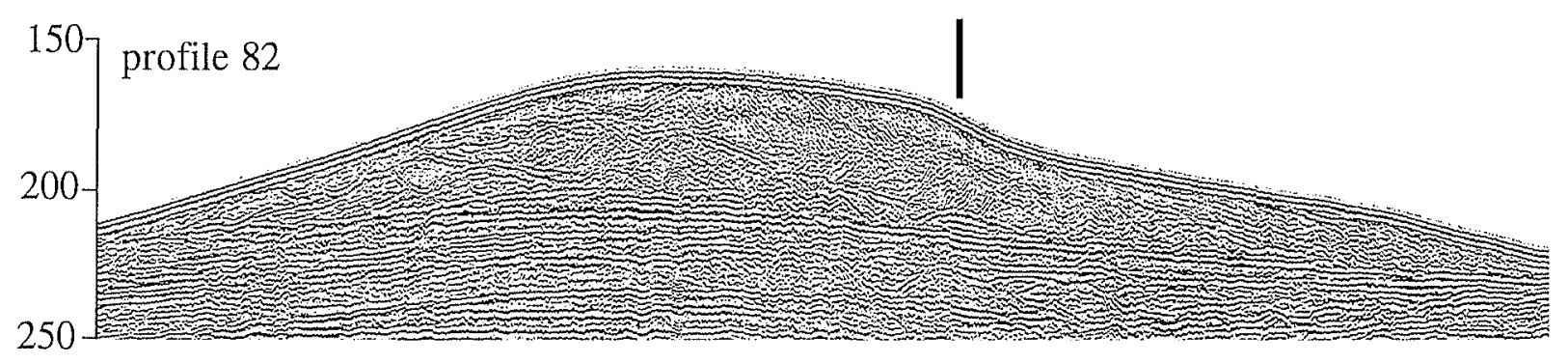

ms twtt

profile 59

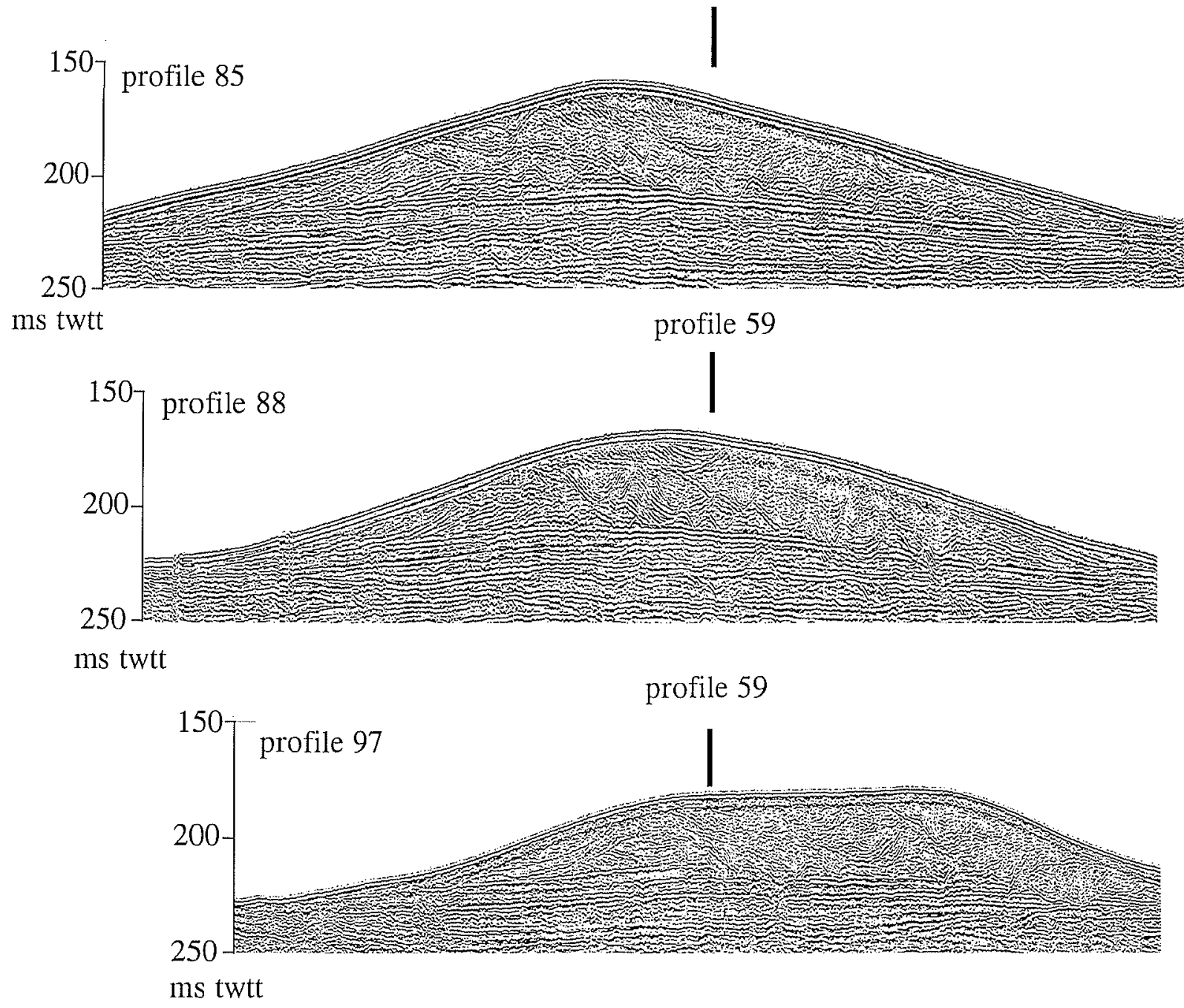

$500 \mathrm{~m} \quad$ Fig. 9a. Evolution of the internal structure across the KIH bank

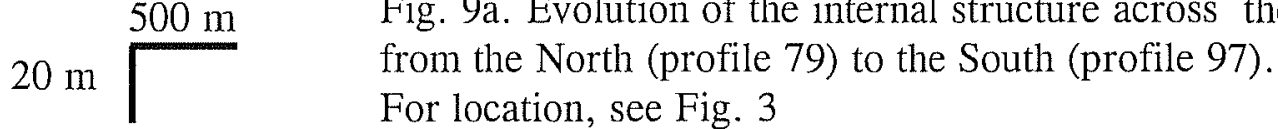




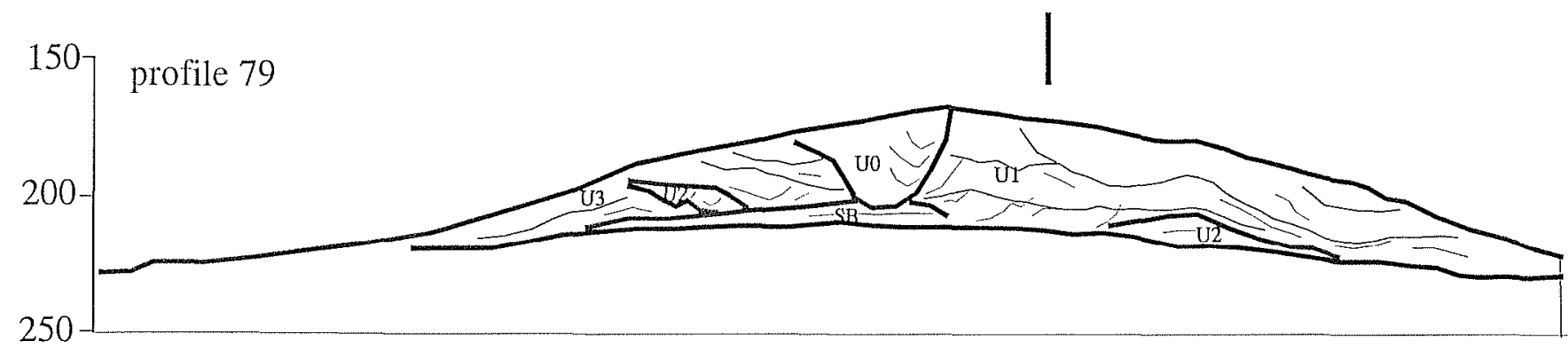

ms twtt

profile 59

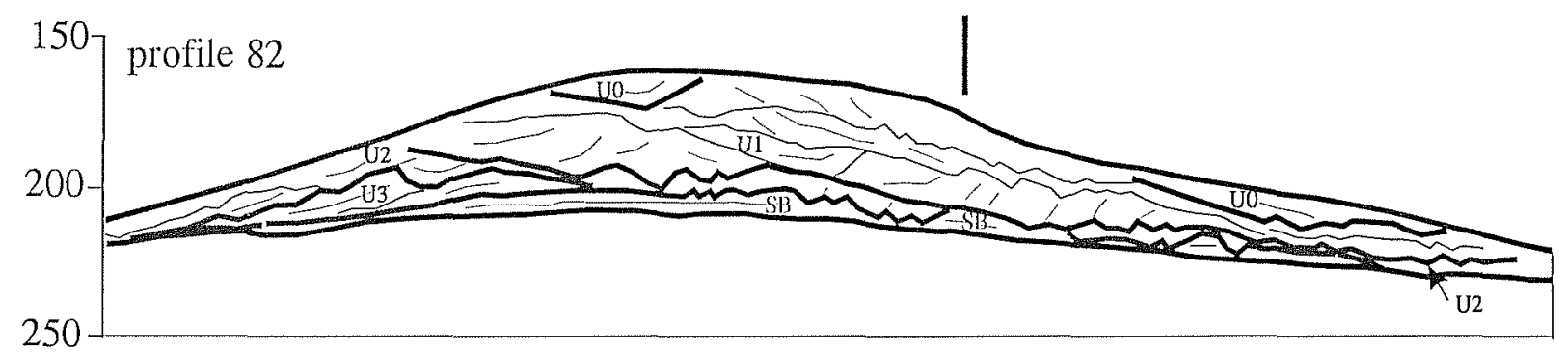

ms twtt profile 59

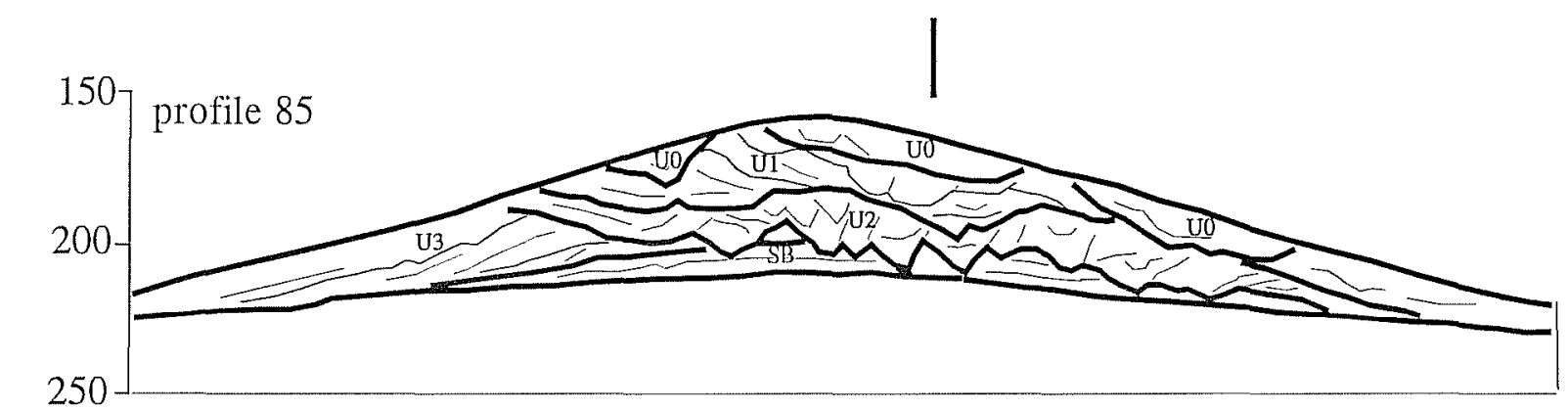

ms twtt profile 59

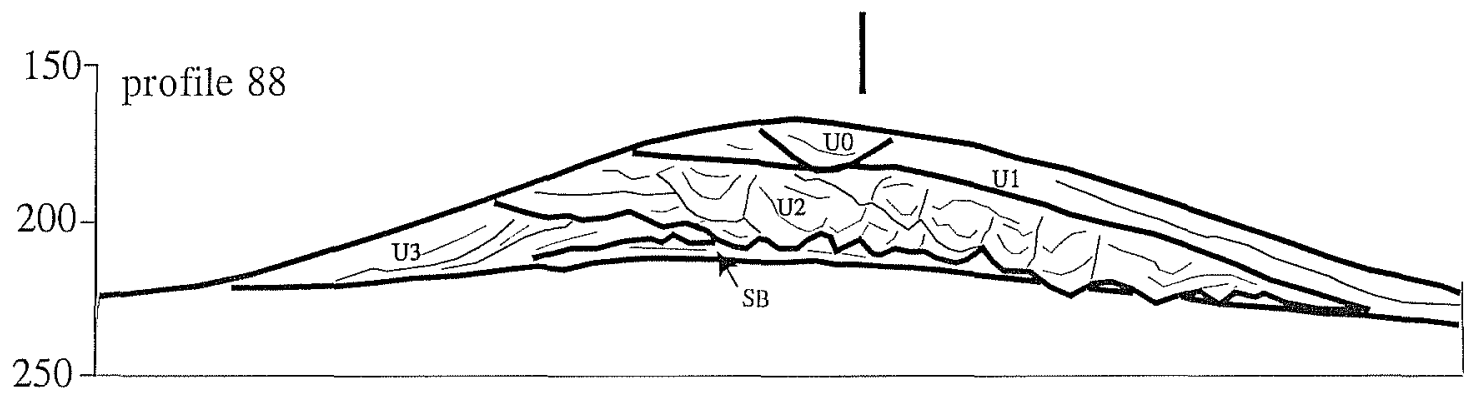

ms twtt

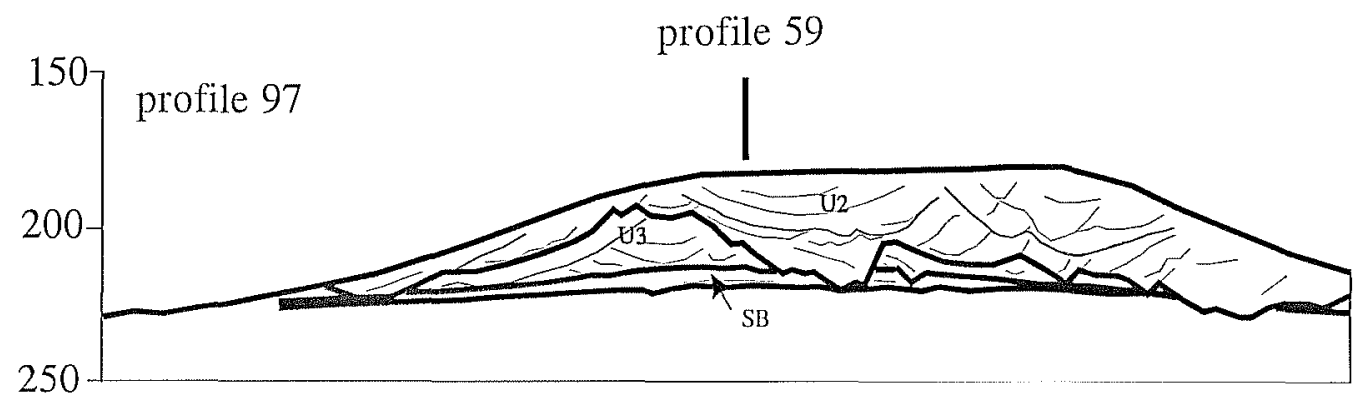

ms twtt

$500 \mathrm{~m}$
$\square$ $\begin{aligned} & \text { Fig. 9b. Evolution of the internal structure across the } \\ & \text { from the North (profile 79) to the South (profile 97). } \\ & \text { For location, see Fig. 3 }\end{aligned}$ 

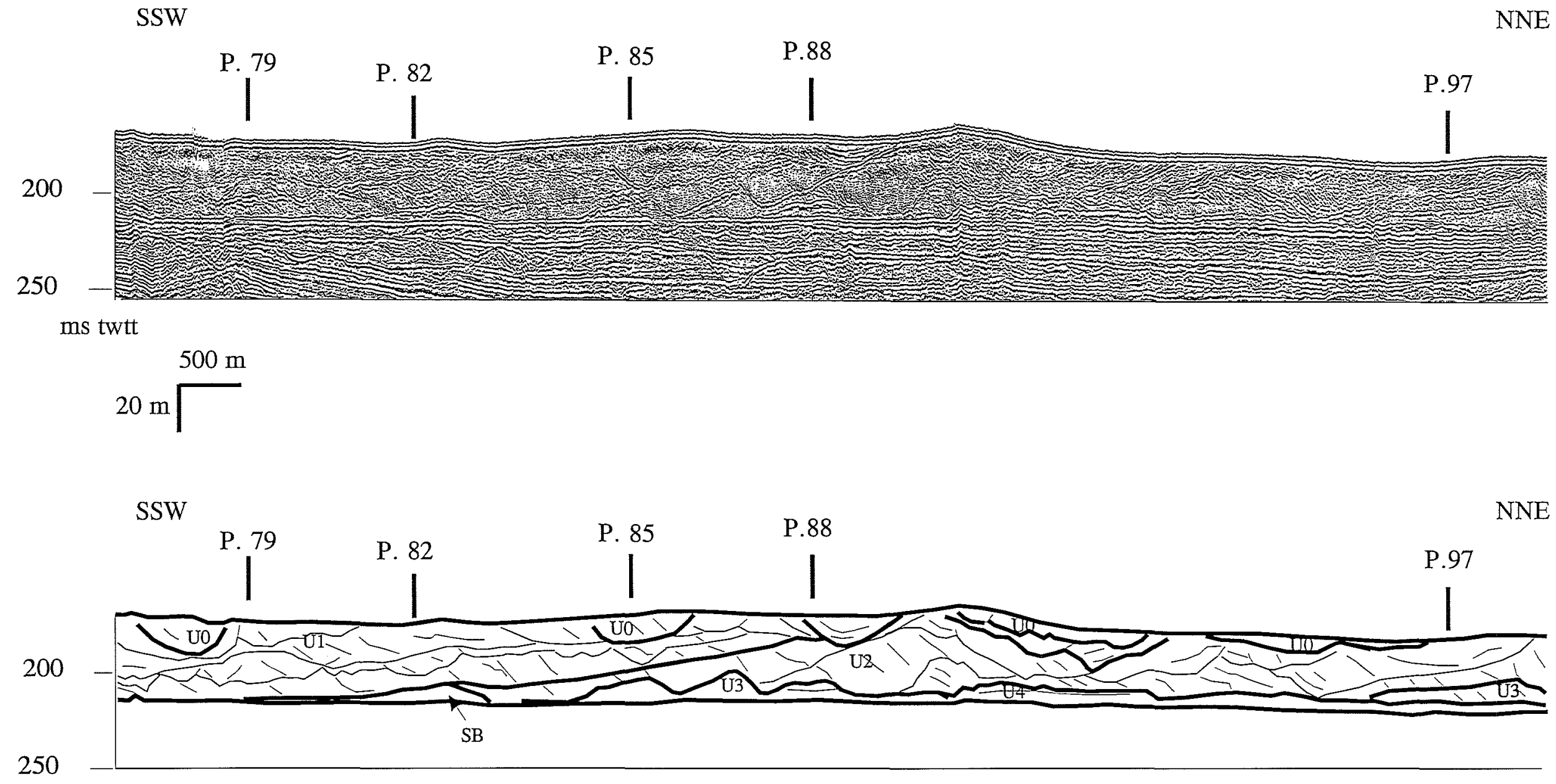

ms twtt

$500 \mathrm{~m}$

$20 \mathrm{~m}$

Fig. 10. Evolution of the internal structure of the bank along the longitudinal profile P. 59 


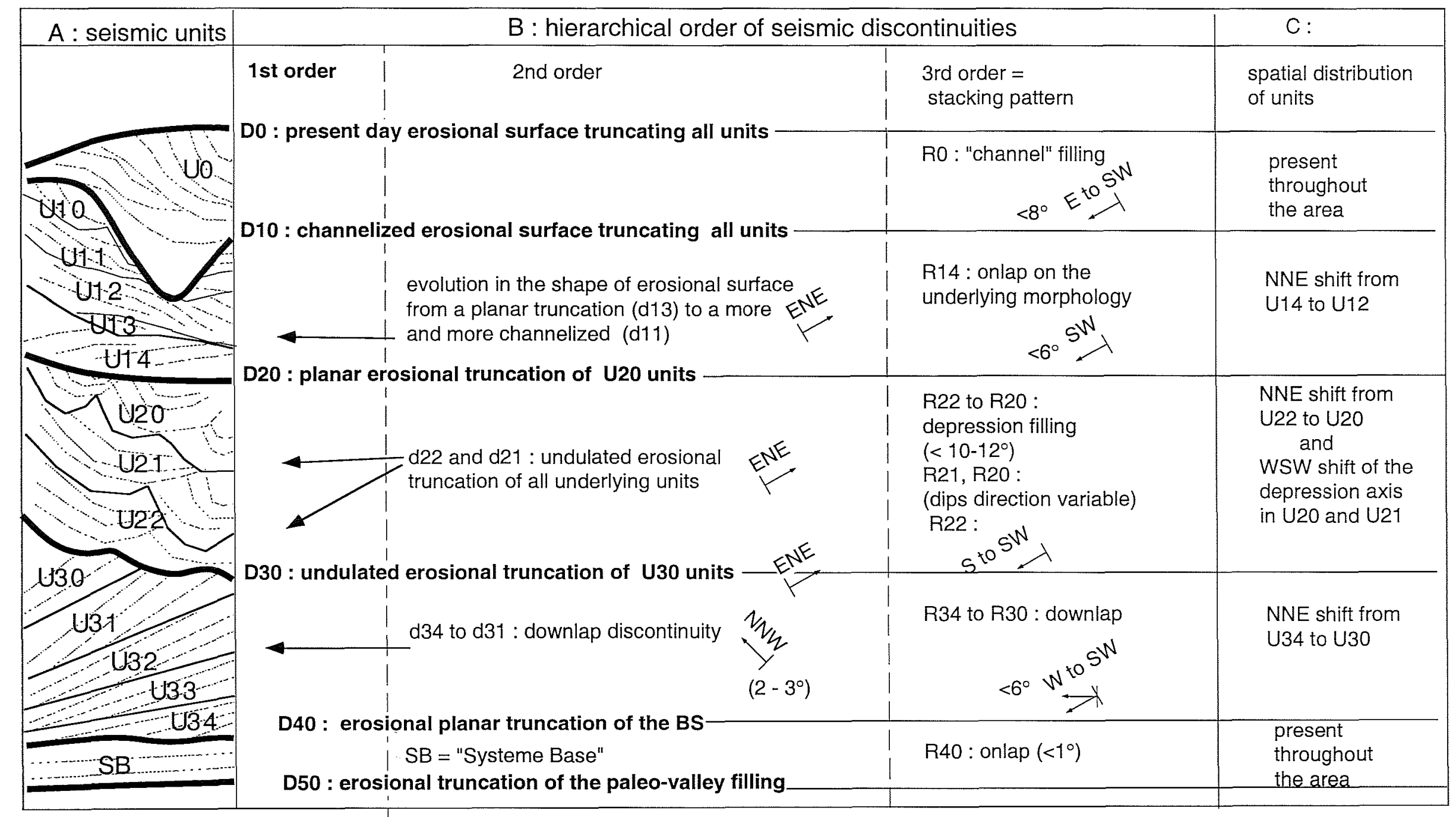

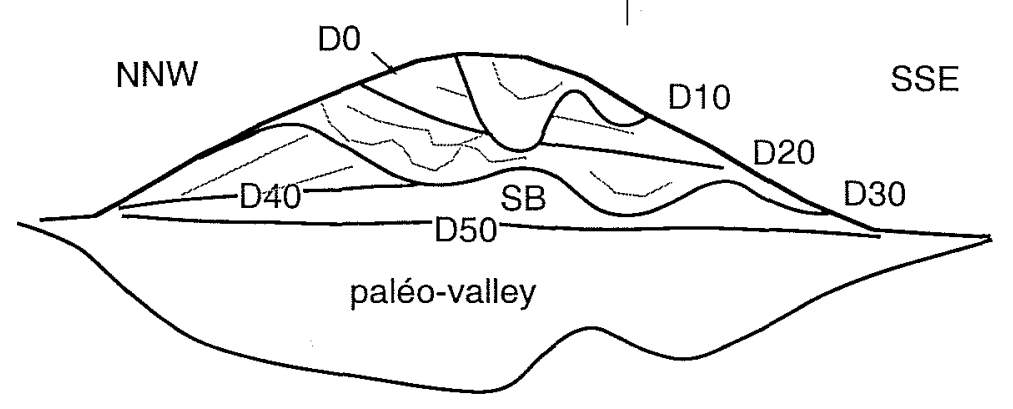

Fig. 11. Characteristics of the internal structure of the Kaiser-I-Hind bank (Belgica 94/ 17 survey, Zone 3) 


\section{U3}

Erosional channel-bank system

External shoal (bank "levee")

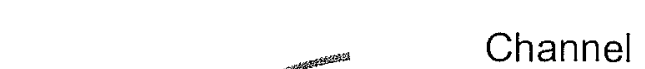

\section{$\mathrm{U} 2$}

\section{Active channel-bank system}

lateral migration of channels
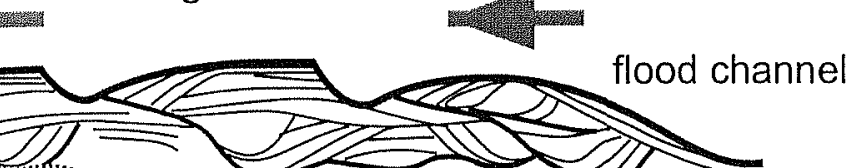

Unit boundary

(migration surface)
Preserved channel

Fig. 12a. Hypothesis of a channel/ levee system

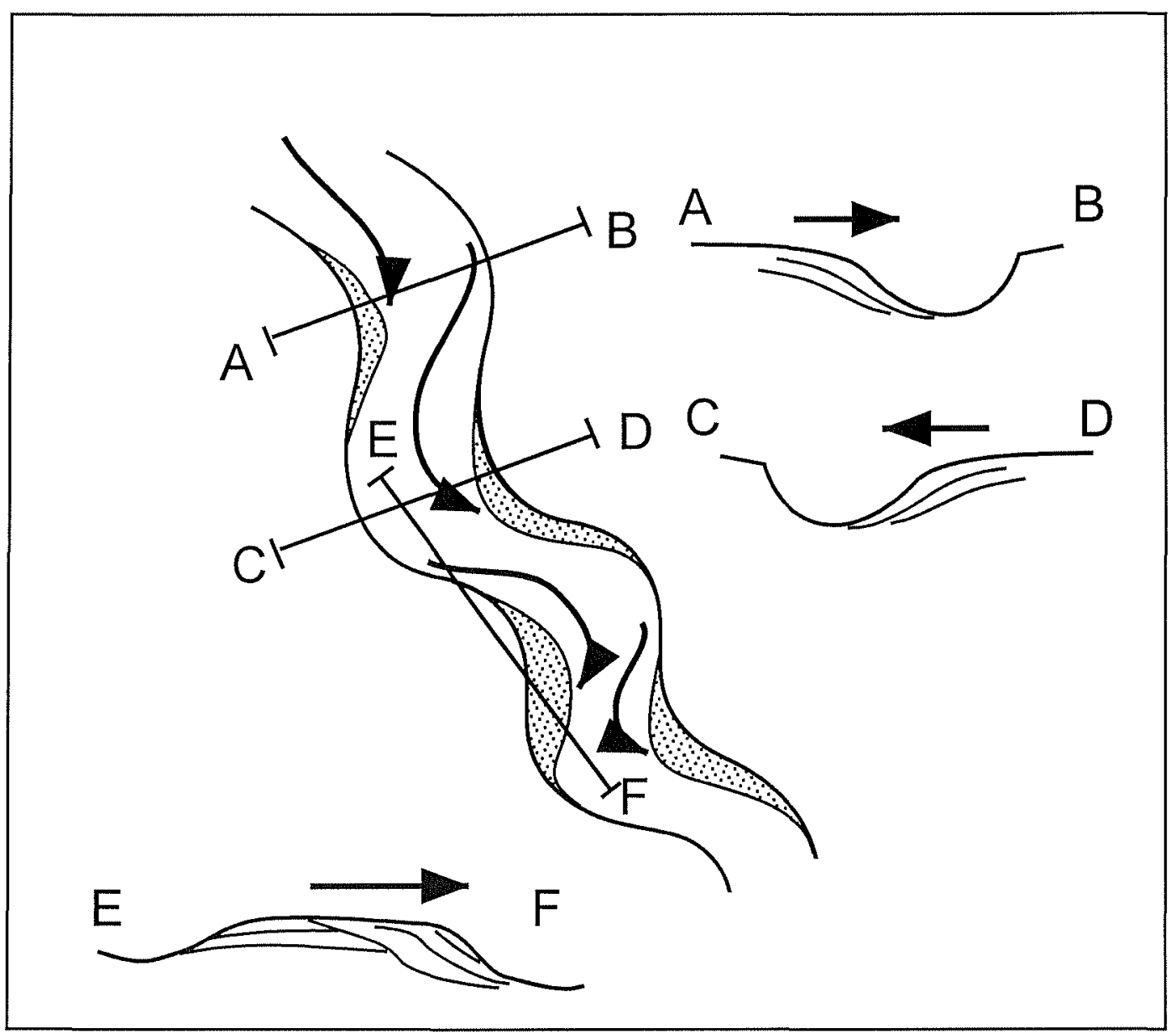

Fig. 12b. Migration of lateral bars with high progradation velocity 


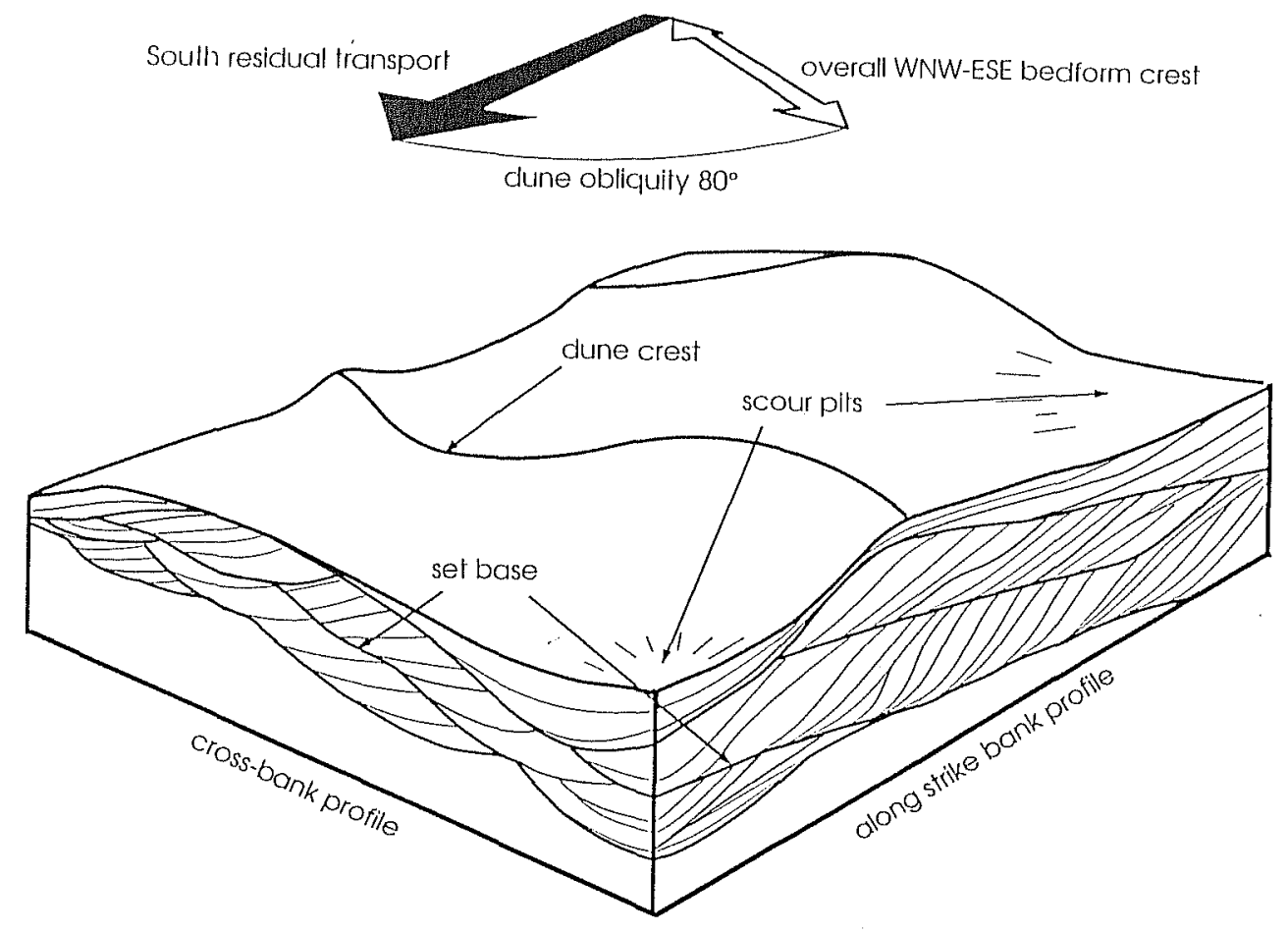

Fig. 13a. Hypothesis of a dunes system : (After Reynaud et al. 1998)

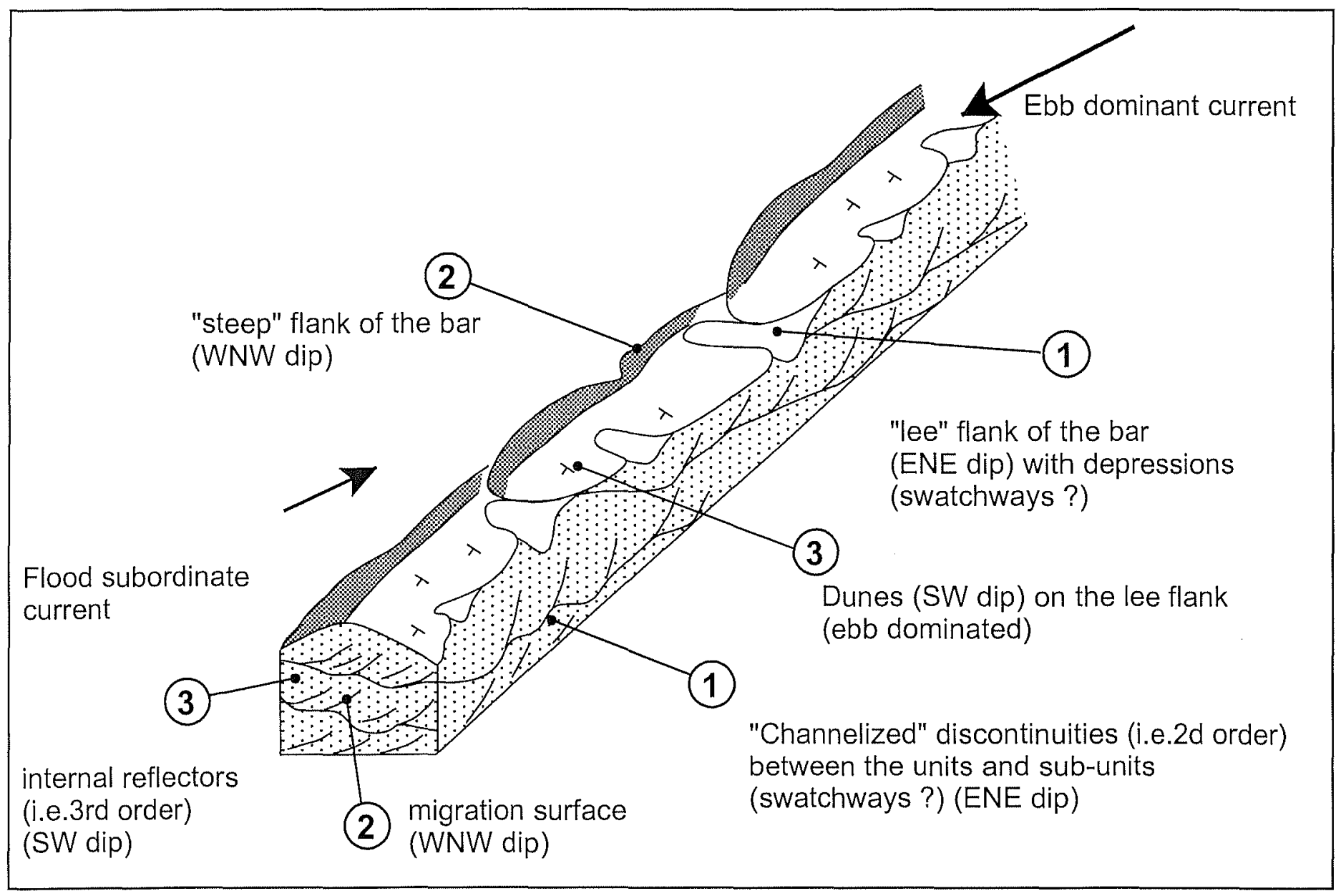

Fig. 13b. Hypothesis of a bar - chain system (After Tessier, 1997) 